Int. J. Dev. Biol. 49: 615-632 (2005)

doi: $10.1387 /$ ijdb. $052023 \mathrm{lb}$

\title{
Gametophyte interaction and sexual reproduction: how plants make a zygote
}

\author{
LEONOR C. BOAVIDA ${ }^{1}$, ANA MARIA VIEIRA ${ }^{1}$, JÖRG D. BECKER ${ }^{1}$ and JOSÉ A. FEIJÓ ${ }^{* 1,2}$ \\ ${ }^{1}$ Centro de Biologia do Desenvolvimento, Instituto Gulbenkian de Ciência, Oeiras, Portugal and ${ }^{2}$ Universidade de Lisboa, Faculdade de \\ Ciências, Dept. Biologia Vegetal, Campo Grande, Lisboa, Portugal
}

\begin{abstract}
The evolutionary success of higher plants relies on a very short gametophytic phase, which underlies the sexual reproduction cycle. Sexual plant reproduction takes place in special organs of the flower: pollen, the male gametophyte, is released from the anthers and then adheres, grows and interacts along various tissues of the female organs, collectively known as the pistil. Finally, it fertilizes the female gametophyte, the embryo sac. Pollen is released as bi or tricellular, highly de-hydrated and presumably containing all the biochemical components and transcripts to germinate. Upon hydration on the female tissues, it develops a cytoplasmic extension, the pollen tube, which is one of the fastest growing cells in nature. Pollen is completely "ready-to-go", but despite this seemingly simple reaction, very complex interactions take place with the female tissues. In higher animals, genetic mechanisms for sex determination establish striking developmental differences between males and females. In contrast, most higher plant species develop both male and female structures within the same flower, allowing self-fertilization. Outcrossing is ensured by self-incompatibility mechanisms, which evolved under precise genetic control, controlling self-recognition and cell-to-cell interaction. Equally important is pollen selection along the female tissues, where interactions between different cell types with inherent signalling properties correspond to check-points to ensure fertilization. Last but not least, pollen-pistil interaction occurs in a way that enables the correct targeting of the pollen tubes to the receptive ovules. In this review, we cover the basic mechanisms underlying sexual plant reproduction, from the structural and cellular determinants, to the most recent genetic advances.
\end{abstract}

KEY WORDS: pollen tube, sexual plant reproduction, pollen-stigma interaction, fertilization, cell polarity

\section{Introduction}

The mechanisms of pollination and fertilization were guessed from the practical utilization of agriculture and seed production more than 5000 years ago, when Assyrian priests had rituals of dusting pollen from the male date palms on the inflorescences of female trees (Fig. 1 A,B). The Greek philosopher, Theophrastus (300 B.C) has also inferred on the union of the two sexes for the production of seed in plants. However, the idea was not generalized until 1682, when the botanist Nehemias Grew stated that pollen must reach the stigma to insure the development of seeds. In 1694 Rudolph Jacob Camerarius published «De sexu plantarum epistole», in which he stated that based upon his experiments there are two different parts of the flower, the stamens and the pistil and that they must work together to produce ripe seed. After Brown's (1833) detailed descriptions, it would be Amici (1824, 1830 ), to firstly observe pollen tubes and its passage down the style and into the ovule (Amici, 1824, 1830, 1847) (Fig. 1 C,D). The contact between the tip of the pollen tube and the egg cell remained unanswered until Strasburger proved that the pollen tube does not stay intact, but its apical tip disintegrates upon contact with the embryo sac and that one of its "nuclei fuses with the nucleus of the egg" (Maheshwari, 1950; Cresti and Linskens, 1999). It was left for Darwin (1862) to prove conclusively the importance of pollination in perpetuation and vigor maintenance of plants. Double fertilization was afterwards simultaneously described by Sergius Nawashin and Leon Guignard in the dawn of the 19th century and nowadays is believed to be a ubiquitous phenomenon (Friedman, 2001).

The male gametophyte in action - the pollen tube

After pollination, pollen is somehow deposited on the stigma surface, where it germinates by re-hydration and development of a fast-growing cytoplasmic extension, the pollen tube. Besides

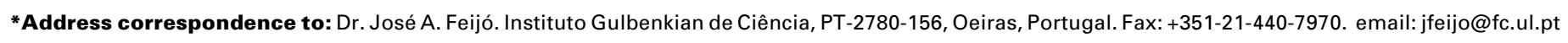



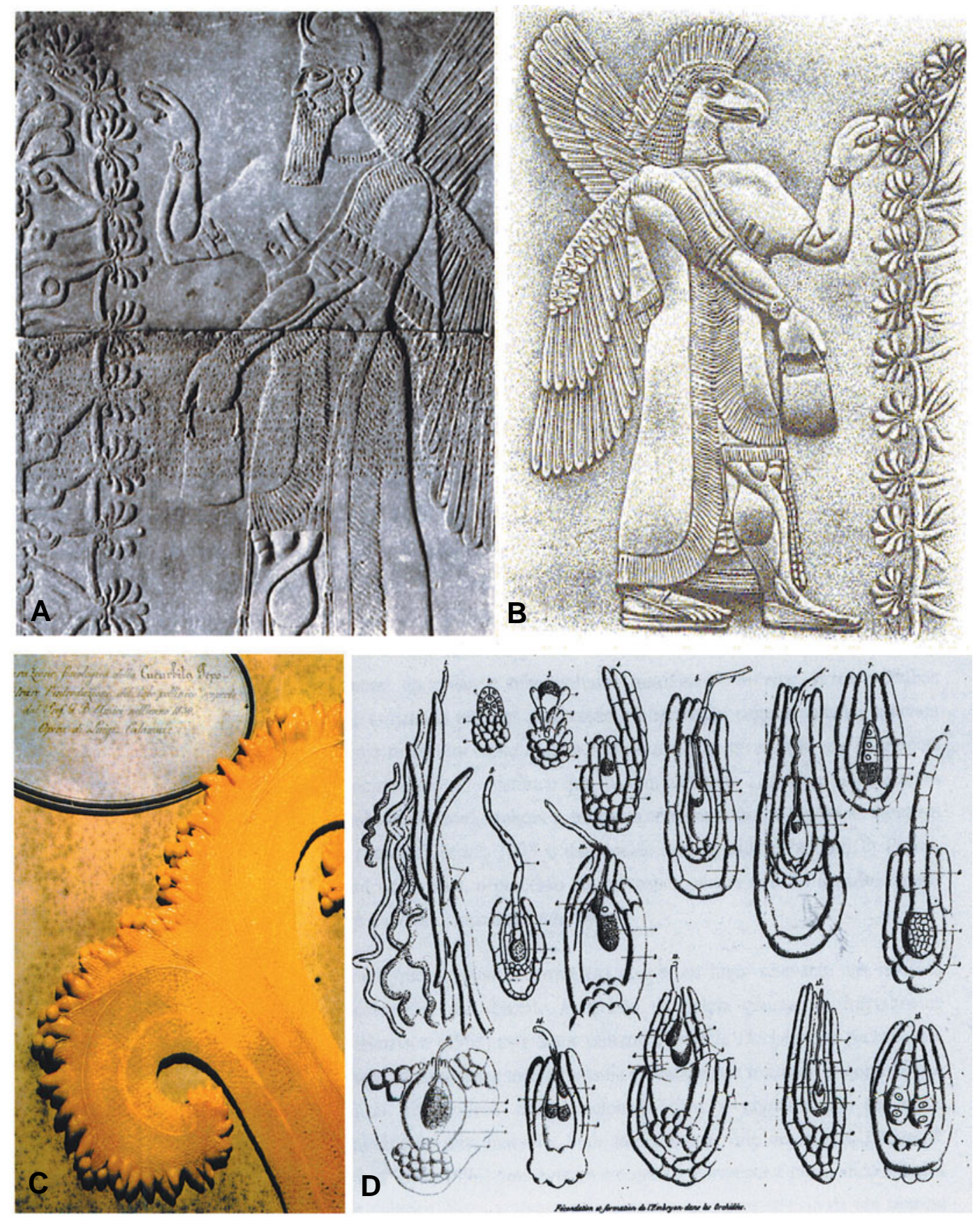

Fig. 1. Historical perspective of the discovery of sexual reproduction in plants. (A,B) Ancient representations of the first historical evidence that pollen had to be brushed on the stigma surface as a means to assure seed production. As long as 5000 B.C. both Assyrian priests (B) and Egyptian gods were pictured on ceremonial fertilization of date palms. (C,D) One landmark of the scientific discovery of the basis of sexual plant reproduction was the precise definition of the pollen tube role in the discharge of the male component made by Giovanni Battista Amici. (C) shows a wax model by L. Calamai and E. Tortori under the supervision of Amici, illustrating a sagital section of the stigma and style of Cucurbita pepo showing the germination and progression of the pollen tube (Amici 1824)(original models are in the Botanical Museum of the University of Firenze, Italy). Amici later moved to explore the especially favourable structural features of orchids. (D) is reproduced from the original paper from Amici (1847) and shows camera lucida drawings of Orchis morio (1 to 8, 14, 15), Orchis mascula (9), Orchis abortiva (nowadays Limodorum abortivum )(10-12) and Orchis maculata (nowadays Dactylorhiza maculata )(13). 1 shows the pollen tubes ("boyaux") reaching the ovaries and b - the transmitting tissue. It is remarkable how the author, using the optics and magnification of those days could so clearly distinguish the differences of the pollen tubes and the transmitting tissue cells. 2. Postfertilized ovule. 3. Next stage of ovule maturation, illustrating the growth of the internal integument. 4. Next stage, with inversion and definition of the mycropyle. 5-8. Fecundation and beginning of embryogenesis. Amici could correctly describe the callose plugs and the discharge in one of the synergids. It took a lot of time and much more sophisticated techniques to see these details with such precision. 9 to 13. Fertilization in other species. 14 and 15, Double embryo formation in Orchis morio. 
their essential role for fertilization, pollen tubes are an excellent model system to study the cellular processes involved in polarity and tip-growth, e.g. cytoskeleton organization, formation and transport of secretory vesicles, endo- and exocytosis, polarized ion gradients and fluxes, periodic behavior and re-orientation of growth (reviewed by Mascarenhas, 1993; Feijó et al., 1995, 2001, 2004; Cheung, 1996b; Hepler et al., 2001). Cytological and molecular studies of these processes are regarded as important both for fundamental studies of fertility control and reproduction in plants and also to elucidate the basic mechanisms in cellular polarization. With limitations some of these could provide templates to explain other tip-growing cells such as fungal hyphae, root hairs or certain specialized animal cells.

Pollen tubes elongate dramatically (up to many centimeters) through the female tissues to deliver the sperm cells into the embryo sac. This growth occurs without further differentiation or division and is restricted to the apical zone, thus depending on the secretion of membrane and cell wall materials at the pollen tube tip (Fig. 2A) (Picton and Steer, 1981, 1983; Lancelle and Hepler, 1992; Roy et al., 1998; Parton et al., 2001). Pollen tubes can be considered one of the fastest growing cells in nature, with rates of up to $4 \mu \mathrm{m} . \mathrm{sec}^{-1}$.

Pollen tubes are intrinsically polarized cells, a feature reflected in an internal differentiation defining distinct intracellular zones (Cresti et al., 1977; Uwate and Lin, 1980; Lancelle and Hepler, 1992; Hepler et al., 2001): (A) the tip domain, rich in Golgi secretory vesicles outlining an inverted cone; $(B)$ the sub-apical domain, enriched in a large population of metabolically active organelles, such as mitochondria, dictyosomes, ER, vesicles and a few large organelles; zones A and B are usually referred to as the "clear zone"; (C) a nuclear domain, containing most of the large organelles and the male germ unit and further back (D) the vacuolar domain, containing a large vacuole which enlarges as the tubes grow (. 2 a-b). Zones C and D show a distinct "reverse fountain" streaming pattern, with organelles moving as fast as $10 \mu \mathrm{m} . \mathrm{sec}^{-1}$. A callose plug isolates the growing part from the remainder of the tube, which eventually dies. Thus, just the front part of the tube is alive and growing.

An important feature of a growing pollen tube is the "reverse fountain" cytoplasmic streaming, in which an ordered forward movement of organelles through the cortical region of the tube undergoes a turnover in the subapical domain moving back centrally, away from the tip of the tube (Iwanami, 1956). Several studies demonstrated the involvement of the actin cytoskeleton in cytoplasmic streaming and the transport of secretory vesicles containing cell wall precursors (Steer and Steer, 1989; Pierson and Cresti, 1992; Derksen et al., 1995; Li et al., 1997). The actin microfilaments are organized in small cables or a meshwork of filaments (Fig. 2C) and are believed to be regulated by a dynamic process of polymerization/ de-polymerization (Lancelle and Hepler, 1992; Miller et al., 1996; Vidali et al., 2001; Feijó et al., 2004). The apical region is essentially devoid of organized filaments, but a mesh of very short and highly dynamic fragments are observed in the subapical region and in less amount in the "clear zone" (Fu et al., 2001; Chen et al., 2002), where vesicles present apparently random brownian-like motion (Pierson et al., 1990). Several genes encoding isoforms of actin expressed in mature pollen grains have been identified (Thangavelu et al., 1993; An et al., 1996; Huang et al., 1996; Huang et al., 1997). During pollen maturation there is a switch from vegetative to reproductive actin isoforms, which are believed to fulfill unique functions during pollen development (Kandasamy et al., 1999).

In recent years proteins that influence cell shape by regulating the organization and polymerization of cytoskeletal filaments were described by different groups. Several actin binding proteins such as profilin, villin and ADF/cofilin act as regulators of actin cytoskeleton assembly and have been shown to play active roles in the control of the differential distribution of organelles and vesicles and in proper growth of the pollen tube (Kim et al., 1993; Staiger et al., 1993; Lopez et al., 1996; Vidali and Hepler, 1997; Vidali et al., 1999; Smertenko et al., 2001; Allwood et al., 2002; Chen et al., 2002; Hussey et al., 2002a; McKenna et al., 2004).

Contrasting with our current knowledge about actin filaments, the role microtubules play in pollen development and tube growth remains unclear. Microtubules are made up of tubulin and are known to interact with microtubule associated proteins (MAP)(Hussey et al., 2002b). Microtubules were proposed to be involved in the regulation of pollen tube morphogenesis and in the maintenance of internal cytoplasmic organization, but not in active pollen tube growth (Joos et al., 1994; Derksen et al., 1995). They also have been shown to regulate the position of the male germ unit (Sorri et al., 1996; Rodriguez-Garcia et al., 2003). Microtubule motor proteins have been isolated in pollen tubes, but their functions are mostly unknown (Cai et al., 1996). The zwichel (swi) mutation, known to affect trichome branching, encodes a mutant kinesin-like calmodulin-binding protein (KCBP). The suz1 and suz3 (suppressor of zwi3) mutants display no phenotype in absence of $z$ wi3 mutation, but interestingly, the double mutant suz1 zwi3, while rescuing the branch defects, is male sterile due to a defect in pollen germination and tube growth. The few pollen tubes that elongate show large spherical bodies, probably vesicles, suggesting that suz1 or swi could have functions on vesicle movement or targeting during pollen tube growth (Krishnakumar and Oppenheimer, 1999).

Recently, an Arabidopsis AFH1 formin was expressed in pollen tubes and shown to be important for maintaining tip-focused cell membrane expansion. The authors suggest that formins located at the cell surface may be mediators of external stimuli to the actin cytoskeleton and thus, AFH1 could be important for mediating the extracellular signals from female tissues and to elicit the proper pollen tube growth response during pollination (Cheung and $\mathrm{Wu}$, 2004, review in Feijó et al., 2004).

In yeast small GTPases control polarity establishment, cytoskeletal organization, polar secretion and cell wall assembly. Recent experimental data provided evidence that a Rop (Rhorelated GTPases from pollen) plays a critical role in coordinating pollen tube growth, probably by modulating tip $\mathrm{Ca}^{2+}$ gradients and actin dynamics (reviewed by Zheng and Yang, 2000; Cheung etal., 2003; Gu et al., 2003). Both immunolocalization and GFP-tagging showed that Rop is localized to the apical domain of the plasma membrane of pollen tubes, probably acting to focus secretory vesicle delivery (Lin et al., 1996; Lin and Yang, 1997; Kost et al., 1999; Li et al., 1999; Wu et al., 2001). Expression of dominant negative forms of Rac/Rop GTPases resulted in reduced actin bundling and inhibited pollen tube growth, whereas their overexpression converted polar growth into isotropic growth, resulting in pollen tubes with balloon tips and a disrupted actin cytoskeleton (Kost et al., 1999; Li et al., 1999). Using the Rac/Rop 

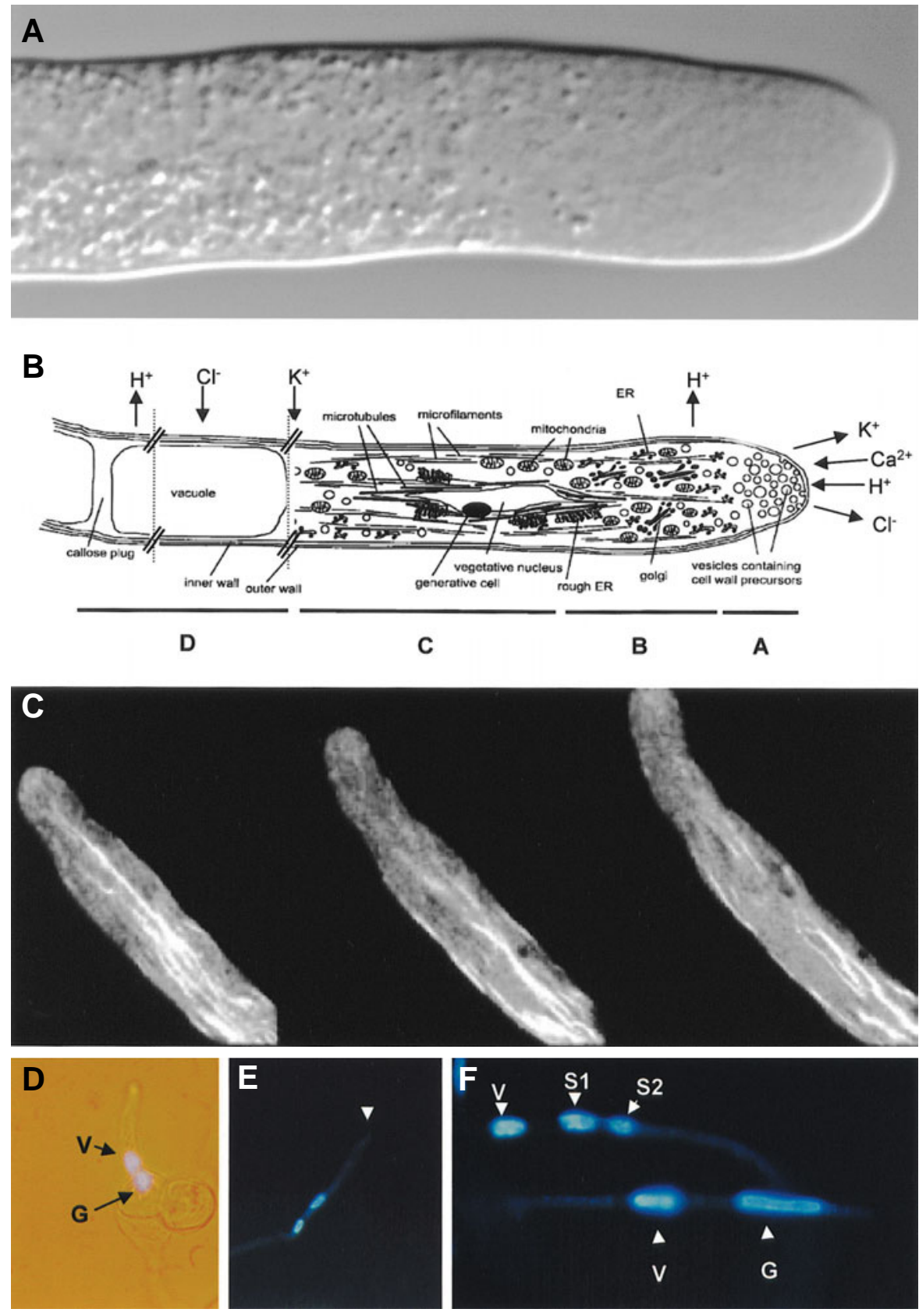

Fig. 2. The male partner - the pollen tube. (A) $D / C$ image of a Lilium longiflorum pollen tube (diameter $15 \mu \mathrm{m})$. The polarisation of the growing tip is striking; the growing apex is devoid of large organelles and presents no organised movement (the "clear zone"). Behind it all the larger organelles are sorted out and move backwards on a fast, organised reverse-fountain streaming pattern. In this species tubes can grow in vitro as fast as $20 \mu \mathrm{m} \cdot \mathrm{min}^{-1}$. (B) Diagrammatic representation of a pollen tube. (A-C) Cytoplasmic domains; (A)Clear zone; (B) subapical domain; (C) nuclear domain; (D) vacuolar domain containing first callose plug (relative length of the domains is not drawn to proportion). Arrows represent ion fluxes known to be important on the establishment of polarity and pollen tube growth. For details see text. Adapted from Franklin-Tong (1999). (C) Time course analysis of growth of a Nicotiana tabacum pollen tube transiently expressing a fusion protein construct of LAT52 (pollen specific promoter), ADF (actindepolymerising factor) and GFP, imaged with twophoton microscopy. The 3 frames are separated by 30 seconds each. Growth of the tube is evident, as well as the fast dynamics of the actin cytoskeleton in the formation and constant reshaping of the fibrils along the pollen tube. A finer meshwork of smaller filaments is present in the subapical area, but this sequence was contrast-optimised to see the long actin filaments that promote the vigorous streaming so characteristic of these cells. (Bar: $10 \mu \mathrm{m}$ ) (adapted from Feijo and Moreno, 2004). (D-F) Sequence of the nuclear migration and division of the generative cell during pollen germination of $\mathrm{O}$.lutea. Both generative cell (G) and vegetative nuclei ( $V$ - in front) enter the pollen tube soon after germination (D). This male germ unit travels at a relatively fixed position form the tip (arrow) (E). Finally, at a timing corresponding to the entrance of the ovule when germinated in situ, the generative cell elongates (bottom tube) and divides into the two sperm cells (S1 and S2- top tube) (nuclei labelled with DAPI)(adapted from Feijó, 1995).
GTPase-induced defective pollen tube phenotype as a functional assay, Chen et al. (2003) have shown that overexpression of NtADF1 suppresses the ability of NtRac1, a tobacco Rac/Rop GTPase, to convert pollen tube tip growth to isotropic growth. This finding suggests that NtADF1 (Nicotiana actin depolymerizing factor1) acts in a common pathway with NtRac1 to regulate pollen tube growth. The mechanisms of docking and fusion of vesicles and the molecular events underlying these processes are not yet understood, but the dynamics of membrane flux was recently addressed by using lipophilic dyes, such as FM4-64 (Parton et al., 2001; Camacho and Malhó, 2003; Parton et al., 2003). The results indicate a dynamic and intrinsically regulated process of endo/ exocytosis present at the tip of the pollen tube, independent of pollen tube growth (Parton et al., 2003). The GFP-NtRab2 fusion protein was shown to function in the secretory pathway between the endoplasmic reticulum and the Golgi suggesting that tip growth and vesicle trafficking are tightly linked in elongating pollen tubes (Cheung et al., 2002). Moreover, two male gametophytic mutants, pok (poky pollen tube) and kinky pollen (kip) show aberrant and reduced pollen tube growth and are known to encode proteins involved in vesicle trafficking (Procissi et al., 2001; Lobstein et al., 2003; Procissi et al., 2003; Lobstein et al., 2004).

The pollen tube wall is differentiated between the primary wall, secreted in the growing tube tip and containing mainly pectin, a middle hemicellulosic layer and an inner secondary wall deposited behind the growing tip, that contains mainly callose (HeslopHarrison, 1987; Derksen et al., 1995). The pectin layer is expected to control the wall dynamics at the growing tip, being plastic enough 
to allow cell extension but also strong enough to support the high hydrostatic pressure exerted by the pollen tube cytoplasm (Steer and Steer, 1989; Benkert et al., 1997; Holdaway-Clarke et al., 2003; Geitmann and Parre, 2004). The finding that unesterified and methyl-esterified pectin epitopes localize in the tip of the wall supports the hypothesis that pectins are polymerized and esterified within the Golgi complex and then transported and deposited in the growing wall by secretory vesicles ( $\mathrm{Li}$ et al., 1995; Li et al., 1997). After deposition, the esterified pectins become progressively de-esterified by the action of pectin methyltransferases (PME) leading to a more rigid form of pectin in the mature pollen wall by crosslink with $\mathrm{Ca}^{2+}$ ions and boric acid (Carpita and Gibeaut, 1993; Li et al., 1997; Li et al., 2002; Holdaway-Clarke et al., 2003). The deposition of the secondary wall starts later and increases gradually in thickness back from the tip. Enzyme complexes are presumably responsible for the production of two types of beta-glucan, the 1,3- $\beta$-glucan callose and the 1,4- $\beta$-glucan cellulose (Ferguson et al., 1998). In Nicotiana both a cellulosesynthase and a glucan-synthase gene have been identified and shown to be predominantly expressed in the male gametophyte. They probably encode catalytic subunits of two $\beta$-glucan synthases involved in pollen-tube wall synthesis (Doblin et al., 2001). In lily two exo- $\beta$-glucanases were also shown to be expressed in pollen tubes and may be involved in the regulation of pollen tube elongation by hydrolyzing callose and 1,3:1,4- $\beta$-glucan within the pollen tube walls (Takeda et al., 2004).

Besides callose and cellulose, several hidroxyproline-rich glycoproteins (HRGPs) have been reported to be present in the secondary tube wall (Cassab, 1998; Showalter, 2001). Examples of these glycoproteins are the pollen-specific extensin-like protein (Pex1) of maize and the pollen-specific glycoprotein NTP303 of tobacco (Weterings et al., 1992; Rubinstein et al., 1995; Wittink et al., 2000). The presence of a conserved leucine-rich repeat (LRR) in the known Pex proteins strongly suggests that this motif is involved in the binding of a specific ligand during pollen tube growth (Stratford et al., 2001). Arabinogalactan-proteins (AGPs) were also identified in the pollen tube walls and thought to have an important role during pollen tube growth. Pollen tubes treated with Yariv reagent, which crosslinks with AGPs are arrested, suggesting a direct role of AGPs in tip growth in monocot species (Li et al., 1995; Jauh and Lord, 1996; Roy et al., 1998; Mollet et al., 2002).

Crucial for pollen tube function is also the presence of membranar receptors for external female stimuli. Several pollen receptor-like kinases (PRKs) of tomato and petunia have an extracellular domain including LRRs, transmembrane domains and intracellular domains and thus are good candidates to play a role in pollen-style recognition. Some of these proteins were recently shown to localize to the pollen tube wall and presumably interact with female ligands (Mu et al., 1994a; Muschietti et al., 1998; Skirpan et al., 2001; Kim et al., 2002; Wengier et al., 2003; Tang et al., 2004). Glycosylphosphatidylinositol (GPI) anchoring provides an alternative to transmembrane domains for anchoring proteins to the cell surface and thus provide another alternative to male-female interaction. Recently, two mutations disrupting SETH1 and SETH2, which encode Arabidopsis homologs of two conserved proteins involved in the first step of the GPI biosynthetic pathway, presented reduced pollen germination and tube growth, associated with abnormal callose deposition (Lalanne et al., 2004). The authors also identified 47 genes that encode potential GPI-anchored proteins expressed in pollen. Most of the identified proteins show homology with proteins involved in cell wall synthesis and remodeling or intercellular signaling and adhesion and thus are likely to play an important role in pollen tube polarization.

Pollen tubes were also the focus of a considerable interest due to the oscillatory nature of their growth, first observed by the periodic formation of thickened cell wall rings occurring in some species, later correlated to fluctuations in the growth rate (review in Li et al., 1997). While the plasma membrane appears to have a smooth continuous membrane underlying the cell wall, it contains ion channels thought to follow a polarized distribution/activation that define the growth axis and also the growing shape (reviewed Feijó et al., 1995, 2001; Holdaway-Clarke and Hepler, 2003). The use of non-invasive methods, such as cytosolic ion concentration imaging, ion vibrating probes and patch clamp have been intensively explored to characterize the physiology of pollen tube growth. It is known for long that pollen tube growth is a $\mathrm{Ca}^{2+}$ dependent process (Brewbaker and Kwack, 1963). Pollen tubes possess a localized gradient of cytosolic free calcium at their apex, which is associated with an extracellular $\mathrm{Ca}^{2+}$ influx (Rathore etal., 1991; Miller et al., 1992; Pierson et al., 1996; Holdaway-Clarke and Hepler, 2003). If the $\mathrm{Ca}^{2+}$ gradient is disrupted, growth ceases in correlation with the dissipation of the gradient. The extracellular influxes of $\mathrm{Ca}^{2+}$ were found to be restricted to the very tip of the pollen tube and both the cytosolic $\mathrm{Ca}^{2+}$ gradient and the inward $\mathrm{Ca}^{2+}$ current were shown to have an oscillatory mechanism that correlates with growth oscillations (Holdaway-Clarke et al., 1997; Messerli and Robinson, 1997; Feijó et al., 2001, Holdaway-Clarke and Hepler, 2003). It is generally accepted that the calcium gradient is maintained by the existence of stretch-activated $\mathrm{Ca}^{2+}$ channels underlying the influx at the pollen tube tip, putatively described by patch clamp on pollen protoplasts by Dutta and Robinson (2004). Analysis of the family of autoinhibited $\mathrm{Ca}^{2+}$ ATPases $(A C A)$ in Arabidopsis, showed that the isoform ACA9 was pollen-specific and its expression was localized at the plasma membrane along all the tube (Schiott et al., 2004). Gene disruptions of the $A C A 9$ coding sequence were found to result in partial male sterility. The aca9 mutant pollen displayed a reduced tube growth potential and a high frequency of aborted fertilization, suggesting that this channel is a regulator of pollen development and fertilization in flowering plants.

Chloride is one of the ions involved in the regulation of pollen tube growth. Large oscillatory extracellular fluxes are closely coupled to oscillatory growth and to the cell volume of the apical domain in the pollen tube tip. The role of chloride effluxes is suggested to be essential for pollen tube to regulate cell volume or turgor pressure (Zonia et al., 2001).

Potassium has been suggested to function as membrane potential regulator and recently a pollen-specific inward $\mathrm{K}^{+}$channel belonging to the Shaker family was isolated. The analysis of spik heterozygous plants revealed impaired pollen tube growth and reduced competitive ability (Mouline et al., 2002).

Cytosolic pH is known to modulate cytoskeleton dynamics, vesicle exocytosis and enzymatic activity in many developmental processes. In pollen tubes a proton influx is localized in the extreme apex, that decreases in the subapical region reverting to an efflux (Feijó et al., 1999). This pattern of fluxes correlates with an intracellular acidic tip and a constitutive alkaline area described at the base of the apical region. Oscillations were shown to correlate 
with growth and extracellular fluxes both at the level of the alkaline area and on the acidification at the tip; protons are believed to enter passively or through low affinity cationic channels at the apex and to be extruded at the subapical domain through plasma membrane $\mathrm{H}^{+}$-ATPases (Feijó et al., 1999). Despite the effort to unveil the major mechanistic components of pollen tube growth regulation, integrative models of their regulation linking ion dynamics, cell wall extension and the intracellular organization remain mostly speculative (Feijó et al., 2001, 2004).

\section{The progamic phase}

The progamic phase corresponds to the progression of the pollen tube through the gynoecium, beginning with germination of the pollen grain and penetration of the pollen tube in the stigma and culminating with the delivery of the sperm cells into the synergid of the embryo sac (Fig. 3A, I-III). When pollen tubes grow on the pistil, they follow invariably the same path. For this reason the pistil was seen for long as a passive structure, just providing nutrients needed for pollen tube growth. However, recent evidence shows a different view and it is now commonly accepted that the pistil plays an active role, perhaps even acting dynamically on the regulation of pollen tube growth. Most of the current knowledge involving the events occurring after contact of pollen with the stigmatic surface was gathered from studies on the self-incompatibility system in several species. Yet substantial information is also available on cell-to-cell communication events and on the molecules involved in compatible crosses (de Graaf et al., 2001; Wheeler et al., 2001; Johnson and Preuss, 2002; Higashiyama et al., 2003; Lord, 2003).

\section{Pollen-stigma interactions}

The stigma can be considered a modified structure for pollen grain capture and reception, germination and initial growth of pollen tubes. The stigmatic surface of different species varies widely in morphology and in the presence or absence of stigmatic exudates. There are two types of stigma, the "dry" and the "wet" types, which differ by the presence or absence of wet sticky secretion, the exudate. It was suggested that in plants with "dry" stigma the pollen coat assumes the role of the exudate present in plants with "wet" stigmas (Heslop-Harrison and Shivanna, 1977; Knox, 1984). The initial contact between the male pollen and female stigma cells includes specific and selective binding of appropriate pollen by the stigma, rapid pollen-recognition, pollen hydration and pollen tube germination and growth.

Crucifers, like Brassica and Arabidopsis, have a "dry" stigma and the epidermis is composed of large specialized papillae cells that interact directly with the surface of pollen. Genetic and chemical papillar cell ablations in Brassica and Arabidopsis led to different results, despite the fact that the processes leading to pollen recognition, hydration and germination appear to be similar. In Brassica the impairment on the biosynthetic activity of papillar cells led to inhibition of pollen tube development, whereas in Arabidopsis pollen tubes were able to germinate and grow in non functional stigmas (Kandasamy et al., 1993; Thorsness et al., 1993).

The first event known to occur when pollen lands on plants with "dry" stigmas is pollen adhesion. Although the biophysical and chemical nature of the adhesion process are unknown it is thought to depend on the deposition and mobilization of components of the pollen coat to the stigmatic surface and is likely to involve also components of the stigmatic surface to promote the formation of adhesion bonds (Heslop-Harrison and Shivanna, 1977; Elleman et al., 1992).

In Brassica oleracea quantitative measurements of the pollenstigma adhesion demonstrated that the nature of the interface contact undergoes structural changes that are correlated with reinforcement of the adhesion contact over time ( 30 min). Pollen coating is one of the major components of this interaction. On the female side, the developmental stage of the stigma and the protein constituents of the stigmatic cuticle are critical for pollen capture, whereas the SLG and SLR1 glycoproteins (involved in self-incompatibility) play a role in later stages (Luu etal., 1997a, 1997b, 1999). Pollen lipids and stigmatic waxes are believed to take part in the formation of a contact interface between pollen and stigma (HeslopHarrison and Shivanna, 1977; Elleman et al., 1992; Preuss et al., 1993). In Arabidopsis a very rapid "initial" adhesion step was demonstrated to rely on the exine coat, but not on the pollen coat (Zinkl et al., 1999). Several mutants showing defects in exine are also defective for adhesion to papillae (Taylor etal., 1998; Zinkl and Preuss, 2000; Paxson-Sowders et al., 2001; Ariizumi et al., 2003).

To date one of the best described signal transduction mechanism in pollen-pistil interactions is the process of recognition in the sporophytic self-incompatibility (SSI) system in Brassica (Schopfer et al., 1999; Kachroo et al., 2001; Takayama et al., 2001). It involves the pollen coat S-locus cysteine-rich protein SCR (also designated SP11) and two stigmatic proteins SLR1 (S-locus related protein) and SLG (S-locus glycoprotein) (Luu et al., 1999; Kachroo et al., 2001; Takayama et al., 2001). Several small cysteine-rich pollen coat proteins (PCPs) were shown to interact with SLG and SLR1 (Doughty et al., 1993; Hiscock et al., 1995; Doughty et al., 2000). Pollen grains that are rejected fail to hydrate on the stigmatic surface (Luu et al., 1999; Doughty et al., 2000; Takayama et al., 2000; Shiba et al., 2001; Takayama and Isogai, 2003).

Recent evidence demonstrates that ligand-receptor kinase signals may be involved in mediating pollen-pistil interactions in compatible pollinations. Two pollen specific receptor kinases LePRK1 and LePRK2 were shown to localize to the pollen tube wall and to associate forming a $400-\mathrm{kDa}$ protein complex. The LAT52 cysteine-rich protein, known to be important in pollen germination and tube growth, interacts with the extracellular domain of the LePRK2 just before germination. One of the female components, LeSTIG1, a pistil specific cysteine-rich protein, binds to the extracellular domains of LePRK1 and LePRK2, displacing binding of LAT52 in vitro. Further components of this signaling pathway are expected to reveal important cell-to-cell communication events leading to pollen tube growth on the female tissues (Muschietti et al., 1998; Kim et al., 2002; Tang et al., 2002; Wengier et al., 2003; McCormick, 2004; Tang et al., 2004).

After the process of recognition and compatible pollination the pollen hydrates and germinates. Although in vitro pollen germination is quite fast, the in vivo timing varies greatly depending on the species, from 15 minutes in Arabidopsis to more than 60 minutes in Brassica oleraceae (Preuss etal., 1993). Aquaporins have been suggested for the transcellular and symplastic selective transport of water and putative candidates to control pollen hydration on the stigma (Tyerman et al., 2002). The screening of an anther cDNA 

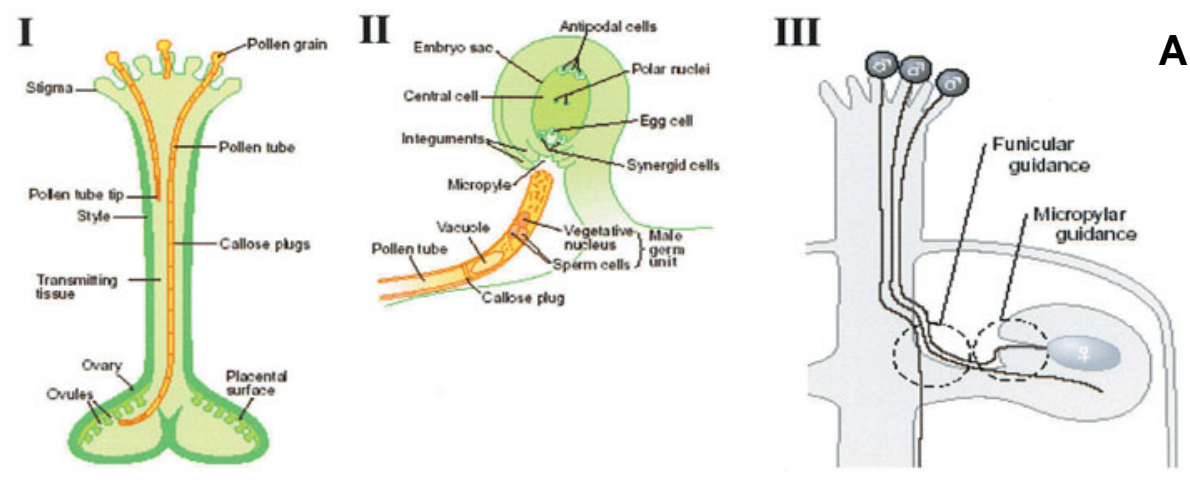

A library in Brassica led to the isolation of two clones, mip $A$ and mipB, which show high similarity with aquaporins. These proteins are probably targeted to the pollen coat (Ruiter et al., 1997). The recessive mutation mod in Brassica encodes an aquaporin and results in the breakdown of the self-incompatible reaction. The water channel was proposed to be a component of the SSI signaling pathway (Ikeda et al., 1997). Moreover, the isolation of a gene, MIP$M O D$, linked to the $M O D$ locus and encoding an aquaporin-like protein,
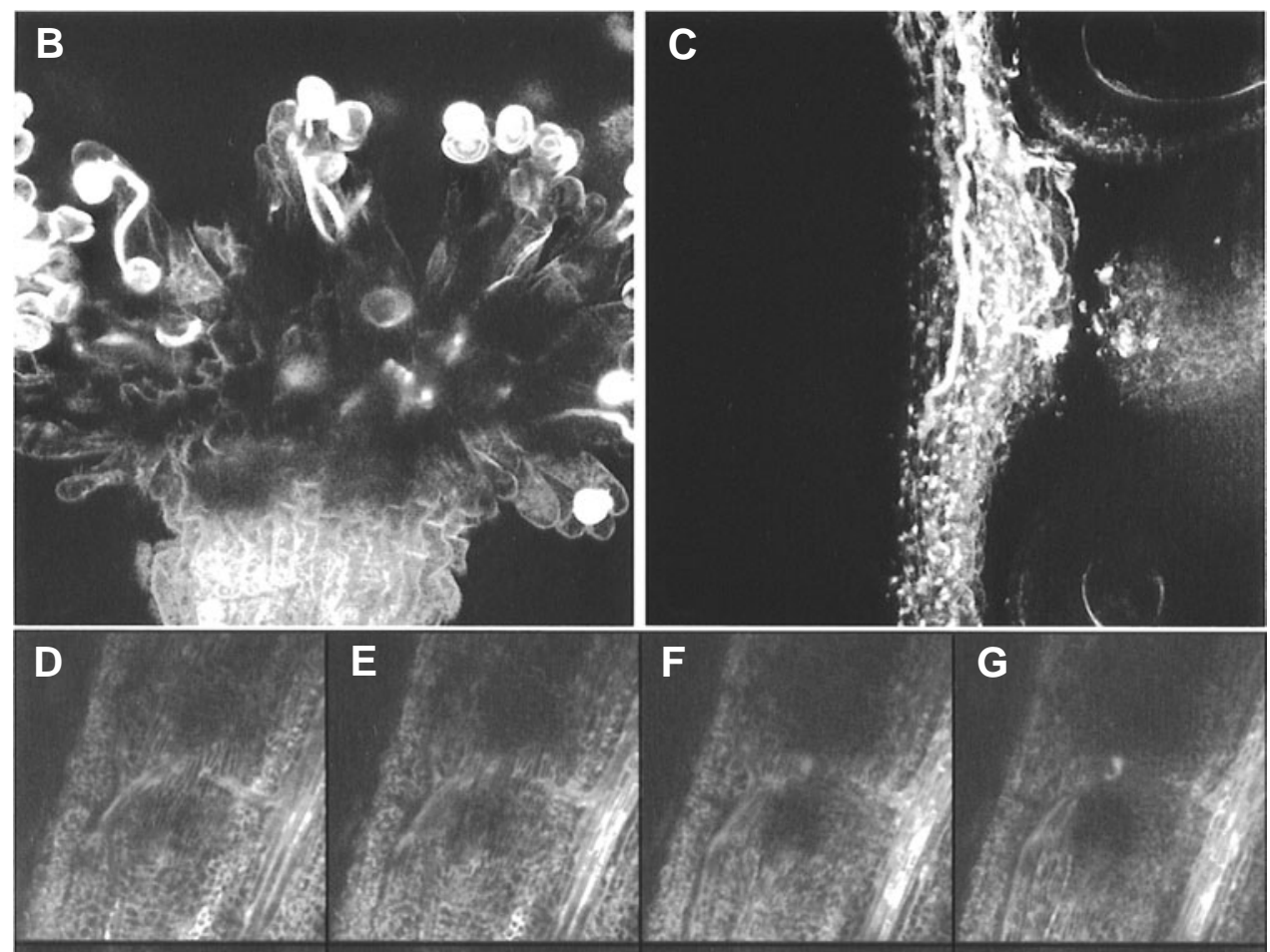

G

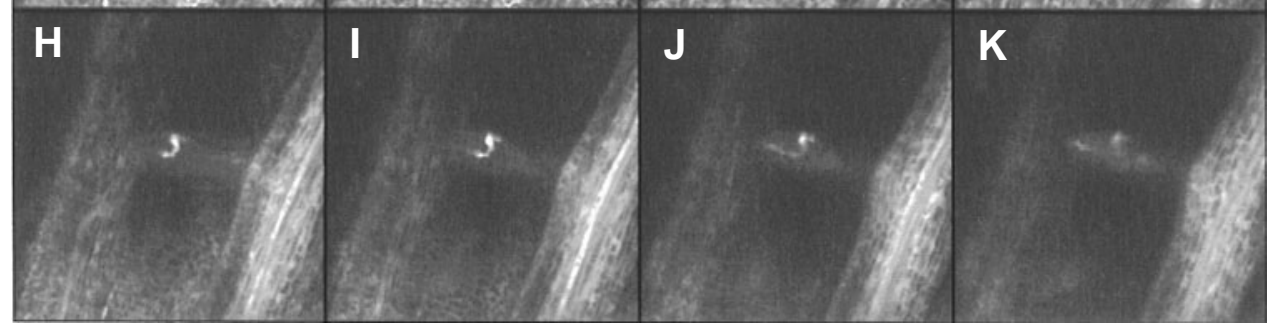
increased the expectations that this type of channels may be involved in the regulation of water transport from the stigma papilla to the pollen grains (Dixit et al., 2001).

Several mutants were identified that showed spatial or temporal disturbances in pollen water control. In raring-to-go mutant plants pollen grains acquire or retain water from the anther, germinating precociously and thus circumventing the required contact with the female stigma (Johnson and McCormick, 2001). Fiddlehead (fdh) shows defects in organ fusion, and wildtype Arabidopsis pollen grains are able to adhere, germinate and produce pollen tubes when applied to vegetative and non reproductive floral organs (Lolle and Cheung, 1993; Lolle et al., 1998). The gene is known to encode a protein showing similarity to a large class of genes that encode proteins related to beta-ketoacyl-CoA synthases and chalcone synthases. The gene may have a role in the biosynthesis of long-chain lipid components that are localized extracellularly, probably modifying the properties of the cuticle (Pruitt et al., 2000). In Arabidopsis mutants that belong to the eceriferum (cer) family with impaired long-chain lipid biosynthesis, the pollen coat composition

Fig. 3. Pollen tube guidance on the pistil. A(I) In a typical compatible pollination, pollen adheres and germinates on the stigma producing a pollen tube, which grows through the female tissues towards the ovary, A(II) where pollen tubes have to adjust their growth trajectory to find an ovule and then turn again to enter in the mycropyle penetrating the embryo sac. Adapted from Cheung and Wu (2001). A(III) Current model for pollen tube guidance involves a funiculus guidance signal that leads the pollen tube to exit the transmitting tissue and a micropylar guidance signal which changes the direction of pollen tubes to the mycropyle. Male-male repulsion, a blocking signal, or cessation of the attracting signal may prevent polyspermy. Adapted from Higashiyama et al. (2003). (B,C) Pollen germination on the stigma and growth through the style and ovary, observed on living material by two-photon imaging of LAT52GFP Arabidopsis pollen tubes. Pollen tubes grow along and around the stigmatic papillae until penetration of the style (B) and then move along the transmitting tissue in bundles (C). (D-K) Optical sectioning through an intact living ovary of A. thaliana, fertilized with pollen transformed with a fusion product of the pollen specific promoter LAT52 and GFP. The whole plant was brought intact into the microscope and the flower bent into a drop of water on top of a Fluor water dip objective lens (60x; NA, 1.0; working distance, $2.0 \mathrm{~mm}$ ). Selected views from a Z-stack made from the external surface of the ovary, past through the epidermis, the ovary locus and a ovule along which a pollen tube crawls into the micropyle. (Bar, 100 um)(adapted from Feijó and Moreno, 2004). 
is also affected and plants are male sterile, showing severe reduction in the ability to hydrate on the stigma (Preuss et al., 1993; Hulskamp etal,. 1995a;Zinkl etal., 1999). Experiments involving the application of exogenous purified lipids to cer mutants were able to bypass pollen hydration specificity and induced heterologous grains to hydrate and germinate pollen tubes (Zinkl and Preuss, 2000).

In species with "wet" stigmas, such as tobacco, the secreting exudate compounds are involved in a variety of processes such as pollen capture, pollen recognition and control of water availability for proper pollen germination. The lipid fraction of the exudates contains many saturated and unsaturated fatty acids, which usually occur as triacylglycerides. Other major components are phenols, proteins, enzymes, glycoproteins and polysaccharides (Cresti et al., 1986). Mutations that eliminate the exudate from stigmas are known to cause female sterility (Goldman et al., 1994; Wolters-Arts et al., 1998). In transgenic stigmaless plants the addition of purified triacylglycerides restored the ability of pollen to penetrate the stigma or other vegetative surfaces, e.g. leaves (Wolters-Arts et al., 1998). Moreover, different lipids have been shown to have effects on pollen grain hydration time, suggesting that lipids may interact with the pollen grain surface (exine, intine, plasma membrane) to change its permeability to water (Lolle et al., 1997; Lolle and Pruitt, 1999; Pruitt et al., 2000; Wolters-Arts et al., 2002). Pollen coat lipids are present in several Brassicaceae species and it is thus less conceivable that they could act as signal molecules to confer species specificity (Piffanelli et al., 1998; Edlund et al., 2004). In contrast to pollen coat lipids, glycine rich proteins (GRPs) are highly divergent across Brassicaceae and thus are best candidates to mediate pollen recognition in a species specific manner (Mayfield et al., 2001; Fiebig et al., 2004).

During hydration the pollen grain has to re-organize the plasma membrane and its cytoplasm in such a way that it restores the metabolic activity and competence to establish a polarity axis leading to the production of a pollen tube that emerges from one of the pollen grain apertures (Heslop-Harrison, 1987; Tiwari and Polito, 1990; Mazina et al., 2002). The signal that determines the place of pollen tube emergency is not known, although water and lipids have been suggested to provide the directional cues that establish polarity (Lush et al., 1998; Wolters-Arts et al., 1998).

Pollen germination is known to be a density dependent process, the so-called "mentor" effect. A small peptide, phytosulfokine- $\alpha$, was shown to promote pollen germination cultured at low density (Chen et al., 2000). Phytosulfokine makes part of a small group of peptides known to have a role in cell-cell communication via receptors (Matsubayashi et al., 2001; Wisniewska et al., 2003).

After pollen germination the style is penetrated and the pollen tube either grows through the papilla cell wall in plants of dry stigmas (Fig. $3 \mathrm{~B}$ ) or is directed through the intercellular spaces between the cells of the secretory region in species with wet stigmas. Penetration of stigmatic tissues is facilitated by the action of cell-wall degrading enzymes present on pollen or pollen tube walls. In grasses the group I of allergens have expansin activity and thus are thought to facilitate invasion of the pollen tube into the maternal tissues by loosening the cell walls of the stigma and style (Cosgrove et al., 1997). Other enzymes such as esterases, pectinases and polygalacturonases may play an important role on breaking or hydrolyzing the stigmatic cell wall (Knox and Heslop-Harrison, 1970; Hiscock et al., 1994; Mu et al., 1994b; Wu et al., 1996; Edlund et al., 2004). A pollen specific polygalacturonase in Brassica was detected on the pollen tube tips during penetration of papilla cell walls (Dearnaley and Daggard, 2001). An abundant secreted peptide in lily, SCA (stigma/style cysteine adhesin), which shows some identity with LTP (Lipid Transfer Protein), has a chemotropic effect in the stigma. Moreover, a small cell wall protein, chemocyanin, which also has chemotropic effect on pollen tubes, is potentiated when combined with SCA in an in vitro assay (Kim et al., 2003; Lord, 2003; Park and Lord, 2003).

\section{Pollen tube growth on the transmitting tissue}

The styles are the structure that establishes the connection of stigma to the ovary. Styles can be classified in three different types according to the structure of the transmitting tissue (TT): they may be open (hollow) styles, solid or semisolid (Knox, 1984; Gasser and Robinson-Beers, 1993). Rows of cells of thick walls connected by plasmodesmata and the pectin-rich middle lamellae constitute the transmitting tissue, which forms a central core in the solid styles, through which the pollen tubes grow trough the cell walls (Figs. $3 \mathrm{C}$, $4 \mathrm{~A}-\mathrm{L}, 4 \mathrm{~J}, \mathrm{~K})$. In the semi-solid style an extracellular matrix (ECM) fills the spaces between the TT cells. In this case the pollen tubes grow along this ECM. In the hollow style one or more layers of glandular cells are lined along the canal of the style. These secretory cells are responsible for the components present on the stylar transmitting tissue, which is known to contain sugars, glycoproteins, proteoglycans, phenolic compounds, aminoacids and proteins (Knox, 1984; Cheung, 1996a; Wheeler et al., 2001).

The components present in the ECM are thought to provide nutrients to pollen tubes, guidance, adhesion and defense against invading pathogens (Clarke and Knox, 1979; Sanders and Lord, 1992; Cheung et al., 1995; Cheung, 1996a). The nutritive role of the TT is primarily supported by the divergence of pollen tube growth rates achieved in vitro, compared with those in vivo. In addition, several experiments demonstrated the incorporation of TT components in the pollen tube or depletion of reserves within the transmitting tissue by the growing pollen tubes (Herrero and Dickinson, 1979; de Graaf et al., 2003).

Hydroxyproline-rich glycoproteins (HRGP) isolated from Nicotiana are thought to be involved in the nutrition of pollen tubes along the transmitting tissue. The Nicotiana transmitting tissue-specific (TTS) proteins belong to the arabinogalactan (AGP) protein family. TTS adhere to the pollen tube surface and tips, promoting pollen tube growth in vitro and in vivo. It was also demonstrated that TTS is incorporated into pollen tube walls and deglycosylated by pollen tubes. Within the transmitting tissue, TTS proteins display a gradient of increasing glycosylation from the stigmatic end to the ovarian end of the style, coincident with the direction of pollen tube growth (Cheung et al., 1995; Wu et al., 1995). The Nicotiana alata homologue was also shown to stimulate pollen tube growth in vitro and to attract pollen tubes in a semi-in vitro system (Wu et al., 2000).

Other glycoproteins show differences in localization, biochemical properties and physiological activity from those described for the TTS proteins in tobacco. The Class III pistil-specific extensin-like proteins (PELPIII) are chimeric HRGP with properties of both extensins and AGPs. PELPIII is localized in the ECM of tobacco stylar transmitting tissue and was shown to be specifically directed into the callose inner wall of the pollen tubes after pollination (Bosch et al., 2001; Bosch et al., 2003; de Graaf et al., 2004). The Galactose-rich Style Protein (GaRSPG) does not promote pollen tube growth and is localized in the cell walls of the TT (Sommer-Knudsen et al., 1998). Thus, the 
biological function of these proteins seems not to be directly related to pollen tube growth, but they may function as structural proteins in the pollen tube walls. Unfortunately, knock-outs of many of these style specific genes and proteins yielded no phenotype and thus their real role remains open to discussion.

The gametophytic self-incompatibility (GSI) system is controlled by a polymorphic S-locus, in which the outcome of pollination is determined by the haploid pollen genotype. This system has been characterized in a number of families, such as Solanaceae, Rosaceae and Papaveraceae (Wheeler et al., 2001; Thomas et al., 2003; Kao and Tsukamoto, 2004). The timing of rejection of pollen tubes on the style has been associated with nutrition requirements corresponding to the switch from an autotrophic growth phase to an heterotrophic growth (Herrero and Hormaza, 1996).

In Solanaceae and Papaveraceae, a S-RNase and a S-gene represent the female and male components, respectively. In the Solanaceae the S-RNase gene, which accumulates on the style, is translocated to the pollen tube cytoplasm, where it triggers a mechanism of RNA degradation in self-tubes (Luu et al., 2000). Several F-box genes isolated in different species, SLF (S locus F-box)/SFB (S haplotype-specific Fbox protein), found to be linked to the $S$ RNase gene and known to be involved in ubiquitin-mediated protein degradation, are the best candidates to confer male specificity in this cell-cell recognition system (Lai et al., 2002; Entani et al., 2003; Ushijima et al., 2003; Qiao et al., 2004, Sijacic et al., 2004). Current models propose that the products of pollen S-alleles are either membrane or cell wall-bound receptors that act as gatekeepers allowing only the self SRNase to enter the pollen tube, or otherwise the cytosolic pollen S-gene product has inhibitory properties, recognizing and inhibiting all S-RNases except those of the same allelic specificity (Thompson and Kirch, 1992; Kao and McCubbin, 1996; Luu et al., 2001). Interestingly, it was shown that SRNases can bind to several pistil proteins in vitro, namely TTS, PELPIII glycoprotein, the $120 \mathrm{KD}$ protein, identi-
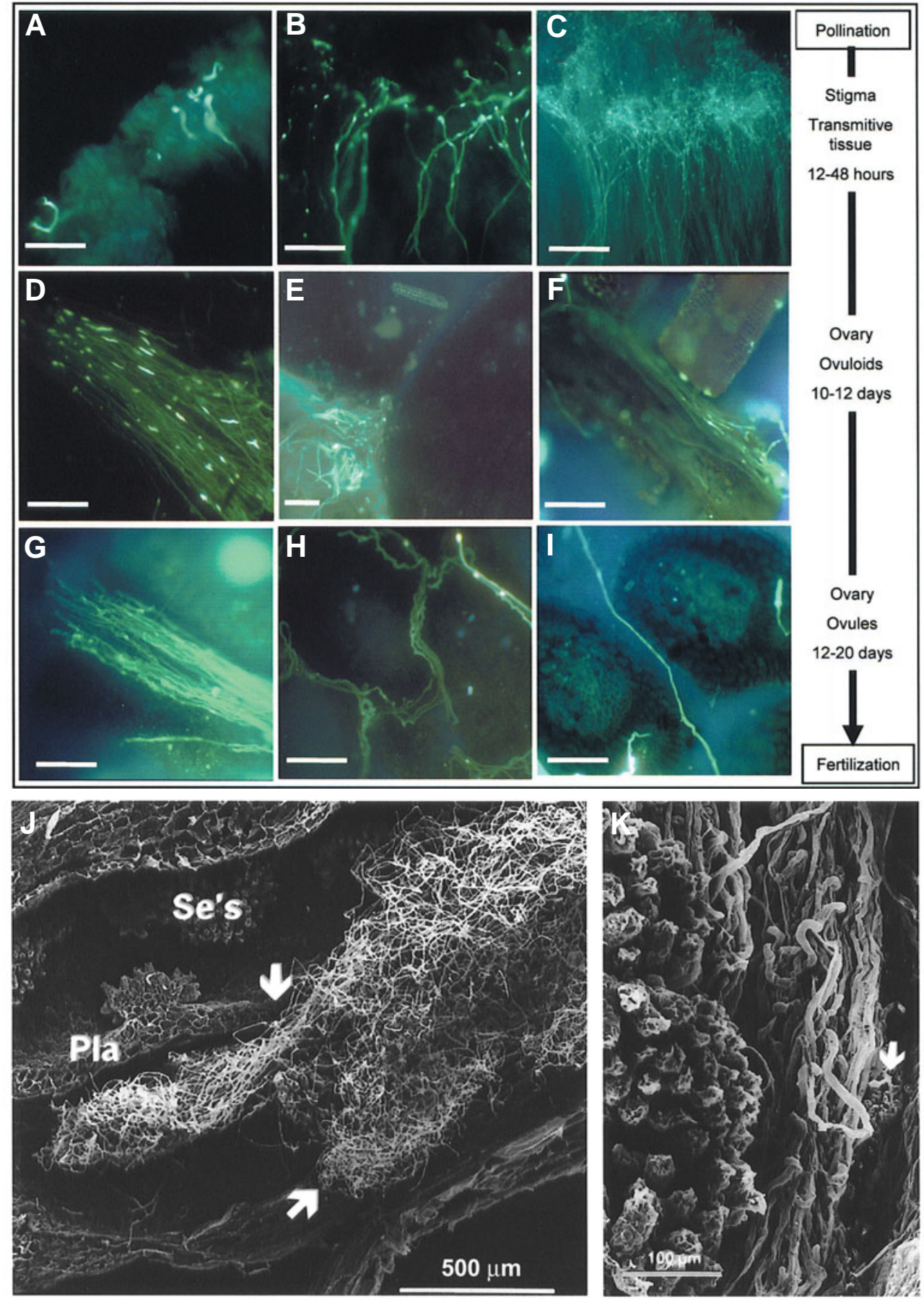

Fig. 4. Pollen tube guidance on the pistil- II. (A-I) Pollen tube progression within the pistil of Eucalyptus globulus. During the first 12 hours after pollination pollen grains germinate in the papillar cells of the stigma (A) and after 24 hours the pollen tubes are growing on the transmitting tissue (B). At 48 hours the pollen tubes are on the upper half of the style (C) and continue growing on the style until $6 \mathrm{~d}$. After passing the obturator they penetrate the ovary after 10 days, where they grow on the upper zone of the placenta through a zone of aborted ovules (ovuloids) (D-F). Only after 12 days they enter the ovular zone of the placenta (G) and grow in the placenta surface around the ovules (H) until targeting the funiculus (I) and consummating fertilization. (Scale bars $=500 \mu \mathrm{m})$. $\boldsymbol{j}$-k. Scanning electron micrographs of pollen tubes of the orchid Ophrys lutea. (adapted from Feijó, 1995). (J) Thousands of pollen tubes progress on the short style without any apparent order, but as soon as the transmitting tissue splits along the sides of the placenta (Pla) tubes divide into discrete 6 threadlike bundles, one on each side of the 3 placentas (arrows). (K) These bundles go along the entire placenta, but tubes "escape" at points to diverge and penetrate the ovule zone (arrow). 
fied in $N$. alata and a $11 \mathrm{kD}$ protein similar to a class of copper binding proteins called phytocyanins. One hypothesis is that S-RNase forms a complex with these proteins in vivo, facilitating the up-take SRNases into pollen tubes (Cruz-Garcia et al., 2003).

Unlike Solanaceae, GSI in Papaver rhoeas does not involve the action of S-RNases and thus S-proteins encoded by the stigma component of the S-locus interact with the pollen S-gene product, this is thought to be a plasma membrane receptor, triggering a $\mathrm{Ca}^{2+}$ dependent signaling network resulting in the inhibition of pollen-tube growth. An interesting signal transduction mechanism cascade has been demonstrated to involve several components such as calcium, phosphoinositides, protein kinases, phosphatases, MAPKs and the fragmentation of F-actin during a process of programmed cell death (PCD)(Franklin-Tong et al., 1991; Snowman et al., 2000; FranklinTong et al., 2002; Franklin-Tong and Franklin, 2003).

The role of the transmitting tissue on pollen tube guidance is still contentious. Two hypotheses were proposed; one relies on chemical cues, the other on the constraints exerted by the physical structure of the TT on pollen tube growth. Evidence for a mechanical stylar guidance was provided by observations that pollen grains placed on longitudinal slits within styles produced pollen tubes that were likely to grow in the direction of the stigma or towards the ovule (Mulcahy and Mulcahy, 1987). Moreover, inverted grafts of styles in lily suggested that pollen tube growth does not follow any polarized chemical gradient (Heslop-Harrison, 1987). However, several stylar proteins are able to promote growth, attract pollen tubes in a semiin vivo system and establish gradients on the pistils (Mollet et al., 2000; Park etal., 2000; Kim et al., 2003; Lord, 2003; Palanivelu et al., 2003). The SCA (Stigma/stylar Cysteine-rich Adhesin) protein isolated from the style of lily combined with another small protein, a lowesterified pectin, was shown to have adhesion properties and stimulate and guide pollen tubes on an artificial adhesion matrix assay (Jauh et al., 1997; Mollet et al., 2000; Park et al., 2000; Park and Lord, 2003). This suggests that this peptide plays a dual role in lily pollination: chemotactic in the stigma and haptotactic (adhesion mediated) in the style.

Recently a role for gamma-amino butyric acid (GABA) in pollen tube growth and guidance was proposed. The Arabidopsis POP2 (pollen pistil interaction2) gene encodes a transaminase that degrades GABA and contributes to the formation of an increasing gradient from stigma to the mycropyle. In vitro GABA was shown to stimulate pollen tube growth, although it had an inhibitory effect at high concentrations. pop2 pollen tubes fail to grow on the pistil, because probably they are not able to degrade the excess of GABA, while wild-type pollen tubes can grow in high concentrations (Palanivelu et al., 2003). However, GABA does not have a chemotropic effect on pollen tubes in vivo, suggesting that other molecules may be involved in this process. Moreover, no GABA-like receptors were identified in the Arabidopsis genome. Therefore, further dissection of the molecular intervenients in this signaling pathway is needed.

\section{Pollen tube guidance and targeting to the ovule}

Once a pollen tube reaches the ovary, it grows along the placental tissue to an individual ovule, reorients to the funiculus and then turns to the mycropyle to reach the embryo sac (Figs. $3 \mathrm{~A}, \mathrm{~B}, \mathrm{D}-\mathrm{K} ; 4 \mathrm{I}-\mathrm{K}$ ). For some time pollen tube guidance was studied mostly by testing chemotropic attraction in in vitro assays. Pollen tubes were chal- lenged to parts of the pistil placed at different distances, to homogenates of pistils or to a large range of molecules, but these experiments led to disappointing and inconclusive results in isolating an active substance in the majority of the cases (Mascarenhas, 1975; Heslop-Harrison and Heslop-Harrison, 1986; Heslop-Harrison, 1987; Reger et al., 1992).

Analysis of pollen tube guidance in several ovule mutants in Arabidopsis indicated that the transmitting tissue should not be considered as a unique factor for pollen tube guidance and pointed at the involvement of an ovule-derived long-range activity that would account for the emergence of the pollen tubes on the surface of the septum and guidance towards the ovules over distances of about $100 \mu \mathrm{m}$ (Hulskamp et al., 1995b). However, the results were not conclusive on whether sporophytic cells of the ovule or the embryo sac itself were the source of such signals. The analysis of gametophytic mutants lacking a functional embryo sac clearly demonstrated the role of the female gametophyte in pollen tube guidance to the ovules. These results led some authors to suggest a model, in which the embryo sac cells are the source of signals that would be responsible directly or indirectly for the diffusion of chemotatic signals that would propagate through the stalk of the funiculus (Ray et al., 1997).

Analysis of magatama (maa) mutants, where the female gametophyte development is delayed, showed two different stages on pollen tube guidance to the ovules. The developmental stage of maa female gametophytes allows pollen tube guidance from the placenta to the funiculus (funicular guidance) but is not sufficiently mature to guide them from funiculus to the mycropyle (micropylar guidance) (Shimizu and Okada, 2000). Supporting these observations is the funicular guidance impairment in the Arabidopsis ino mutants, in which the outer integument does not develop, but the female gametophyte is normal (Baker et al., 1997). The funiculus guidance would work over a long distance from the transmitting tissue to the end of the funiculus $(50-80 \mu \mathrm{m})$, whereas a micropylar guidance signal would be required over a short distance (Fig. 3 A-III). The failure of one pollen tube to enter the mycropyle is usually followed by the approach of another pollen tube, suggesting that the neutralization of the attraction signal would reside in one of these steps to prevent polyspermy.

In order to further study pollen tube guidance, a set of elegant experiments was designed around a semi-in vivo system using Torenia fournieri, which showed that the final attraction step of pollen tubes to the ovule resides on the female gametophyte. The naked female gametophyte protrudes from the mycropyle, making the observation of the pollen tube entering in the embryo sac possible. In this unique system pollen tubes grow through a pollinated pistil to a growth medium and were shown to be attracted to the excised Torenia ovules (Higashiyama etal., 1998). Cell ablation experiments on ovules were successfully used to show that the two synergids on the embryo sac were the source of the diffusible attraction signal, effective at a distance of 100-200 $\mu \mathrm{m}$. Disruption of the central cell, egg cell and integuments did not have any effect on the ability to attract the pollen tubes and a single synergid was sufficient to generate the attraction signal (Higashiyama etal., 2001). An interesting observation in this system was the prerequisite of pollen tube growth through the female tissues to acquire "competence" to respond to guidance cues. These results suggest that interactions with the female tissues may modify the physiology of pollen tubes.

It is still unknown whether the guidance signal emanating from the 
synergids may act directly as diffusible factor on pollen tube attraction or may also act indirectly contributing to the funicular guidance by changing the properties of the ECM of sporophytic cells (Lord and Sanders, 1992; Lush, 1999; Higashiyama et al., 2003). A theory supporting a surface gradient established by a diffusible factor at distances of $100 \mu \mathrm{m}$ can only be reasonable, if a small signaling molecule of less than $1 \mathrm{kDa}$ would be involved. Electric, ionic or gaseous gradients are plausible candidates for a long range activity (Crick, 1970; Ray et al., 1997; Prado et al., 2004).

Although the chemical that acts as a directional signal for pollen tube growth is presently unknown, the species specificity of the signal is not consistent with the classical hypothesis that calcium ions derived from the synergid act as attractants (Huang and Russell, 1992; Mascarenhas, 1993; Malhó and Trewavas, 1996; Tian et al., 2000). Nitric oxide (NO), a small and highly diffusible gaseous molecule, fulfils several of the chemical requirements of a signal molecule and has been implicated in a number of developmental processes in animals and plants (Lamattina et al., 2003). These features led us to investigate this molecule as an inducer of pollen tube re-orientation (Prado et al., 2004). NO was shown to be endogenously produced on peroxisomes by pollen tubes, but absent from the pollen tube tip. Challenging of pollen tubes with an external NO source caused a transient growth arrest, followed by re-orientation. Downstream events on this signaling pathway seem to involve cGMP. Pollen tube negative tropism and growth is regulated by changes in NO levels at the tip of the pollen tube. An NO source could thus be present on the sporophytic female tissues, either localized on the basis of the funiculus to direct pollen tubes to the mycropyle or in sporophytic cells near the embryo sac to prevent polyspermy after fertilization. Evidence in vivo is still lacking, but the indication that an AtNOS1 mutant shows fertility defects (Guo et al., 2003) looks promising for a role of $\mathrm{NO}$ in pollen tube guidance or female fertility (Feijó et al., 2004). The emerging role for a set of small peptides on plant signaling, some of them with chemotropic properties make them likely candidates, which may provide the specificity required for this mechanism (Chen et al., 2000; Matsubayashi et al., 2001; Lindsey et al., 2002; Kim et al., 2003; Wisniewska et al., 2003). In maize, the EGG APPARATUS 1 was just recently described and specifically fulfills these criteria (Marton et al., 2005).

\section{Double fertilization}

The improvement of light microscopy in the 19th century allowed S. Nawashin and L. Guinard to describe two independent fertilization events in the embryo sac, one involving the union of a sperm with the central cell, leading to the endosperm and another involving the union of a sperm cell with the egg cell, which gives rise to the embryo. The origin of double fertilization is thought to have evolved from an ancestral condition in angiosperms, in which more than one nucleus was fertilized in the female gametophyte. An evolutionary genetic benefit arose from a second nutritive fertilization leading to endosperm development and assuring the success of the sibling embryo development (Friedman, 1995; Friedman and Williams, 2004).
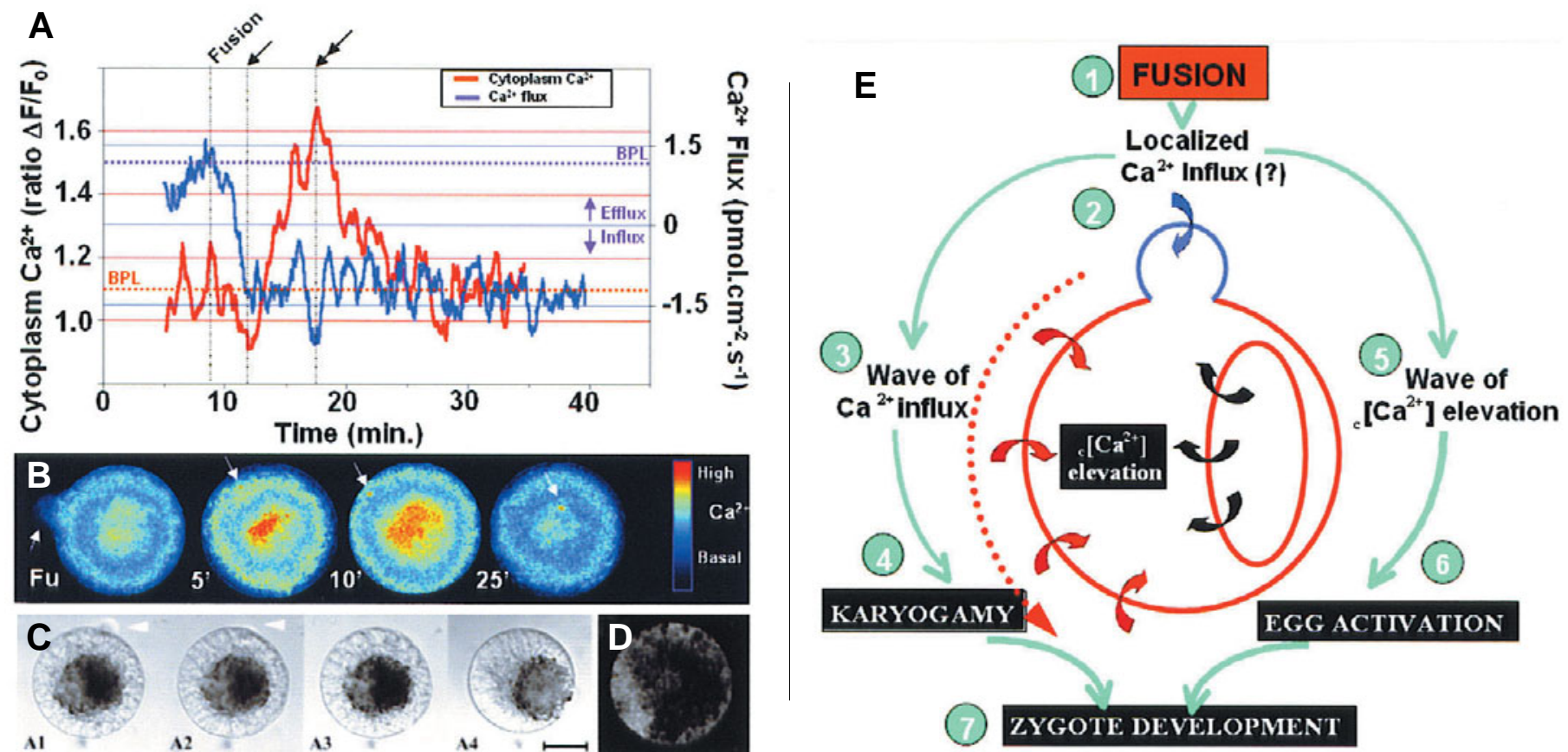

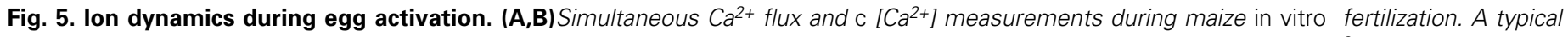

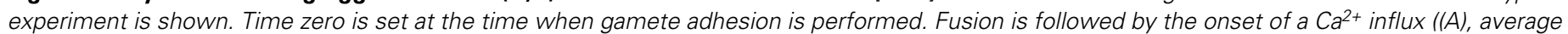

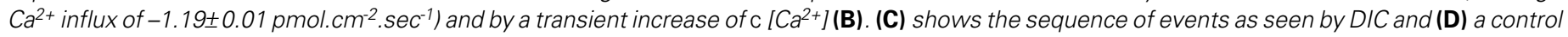

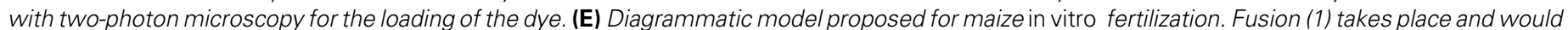

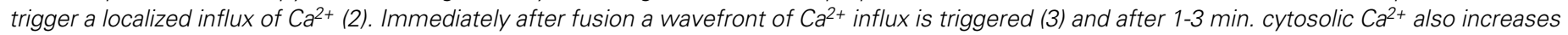

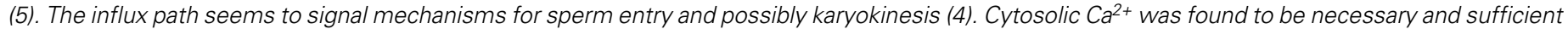

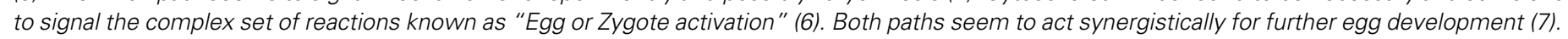
Adapted from Antoine et al. (2001). 
Considerable progress was achieved in recent years on the understanding of the fundamental mechanism behind double fertilization, especially through the development of in vitro fertilization techniques and the use of new model species (Kranz and Lorz, 1993; Higashiyama et al., 1997; Antoine et al., 2000). Furthermore, the major ultrastructural events occurring during the fertilization process in Arabidopsis were described (Faure et al., 2002).

A pre-requisite for successful fertilization is the synchronization of receptivity in all the organs and cells involved in the process. A range of signals induced by pollination are described in several species that induce physiological changes on the pistil and are related with the maturation of female gametophyte and pistil tissues (O'Neill et al., 1993, Zhang and O'Neill, 1993, Mol et al., 2000).

After reaching the embryo sac, the pollen tubes enter the filiform apparatus into the receptive synergid, growth arrests, the tip of the pollen tube ruptures to release the sperm cells and the male germ unit dissociates (Higashiyama et al., 2000). In Arabidopsis pollen tube discharge was shown to occur 2-3 minutes after entry in the synergid (Rotman et al., 2003). The receptive synergid undergoes cell death and this process may occur either before or after pollen tube arrival. Two aggregates of actin filaments, named "coronas" become organized during synergid cell death, one extending to the vicinity of the egg nucleus and the other occurring in the interface of the egg cell and the central cell extending to the polar nuclei. These actin aggregates are thought to be involved in pollen tube reception and help sperm cells to move and bind to their targets (Huang and Russell, 1992; Huang et al., 1993; Huang and Russell, 1994). In the Arabidopsis female gametophytic mutant gf2 (gametophytic factor2), known to encode a DnaJ chaperonin localized in the mitochondria, the synergids fail to degenerate, but embryo sacs are able to attract pollen tubes, indicating that synergid degeneration in Arabidopsis is not an absolute requirement for pollen tube attraction (Christensen et al., 2002).

Pollen tube discharge and the consequent release of sperm cells seem to be controlled by the female gametophyte. In feronia (fer) and sirene (sir) mutants, pollen tubes keep growing throughout the embryo sac after entering it, occupying part of the central cell space and failing to discharge the sperm cells (Huck et al., 2003, Rotman et al., 2003). In feronia, synergid degeneration fails to occur, as demonstrated by normal expression of synergid-specific GUS marker lines. Apparently, no synergid rupture happens after pollen tube penetration, suggesting that a molecule present on the synergid is directly or indirectly responsible for male gamete delivery (Huck etal., 2003). Morever, the embryo sacs of these mutants attract more than one pollen tube indicating that interactions between gametophytes prevent in some way attraction of additional pollen tubes.

Male and female gametophytes must also be synchronized with respect to the cell cycle to result in a successful genetic fusion product, which seems essential for the transition of the zygote to mitosis (Friedman, 1999). After pollen tube discharge the cytoplasmic content is spread inside the degenerated synergid occupying the intercellular space between the central cell and the egg cell, where gamete fusion (plasmogamy) is thought to occur (Higashiyama etal., 2000; Rotman etal., 2003). One sperm cell fuses with the egg cell and the other with the central cell, giving rise to the embryo and endosperm, respectively (Russell, 1992).

The development of an in vitro fertilization system was extremely useful to reveal the cytological and physiological events of sperm- egg cell and sperm-central cell fusion in maize (Kranz and Lorz, 1993; Faure et al., 1994). The combined use of a calcium-selective vibrating probe with advanced imaging techniques demonstrated that gamete fusion triggered a calcium influx in the vicinity of the sperm entry site, which was followed by an increase in cytosolic calcium. The calcium influx spread subsequently through the whole egg cell plasma membrane as a slow wave front, which was shown to be correlated with cytological modifications induced by fertilization, such as egg cell contraction, cytoplasmic calcium elevation and cell wall assembly (Antoine et al., 2000). When calcium influx was inhibited, the sperm cell fused, but was not incorporated in the egg cell. An intracellular calcium increase still occurs, presumably due to calcium release from internal stores and egg activation proceeds normally, suggesting that calcium influx is thus required for sperm incorporation and karyogamy (Fig. 5)(Antoine et al., 2001).

In some species pollen mitosis II is asymmetric and the generative cell divides to produce two sperm cells with different cytoplasmic features visible at the nuclear or cytoplasm content level. It was proposed that this sperm cell dimorphism may be predetermined, giving rise to the concept of preferential fertilization (Russell, 1985; Knox etal., 1993; Faure etal., 2003). This would imply that some kind of pre-determination exists, in which sperm cells fuse with the egg and the diploid central cell nuclei, determining ultimately two different cell fates, the embryo and the endosperm. Under this view it is reasonable to speculate that they are endowed with some kind of molecular specificity that presently is not known (Raghavan, 2003; McCormick, 2004).

Some species seem to have evolved an alternative reproductive mechanism, apomixis, in which seed develops without any sort of fertilization. Apomixis is characterized by two important events: (1) the formation of an unreduced female gametophyte (apomeiosis) and (2) independent embryo development (parthenogenesis) that leads to the development of seeds enclosing a fertilization-independent embryo and in some cases to autonomous endosperm development. Several mutations in Arabidopsis have provided insights in some of the genes leading to apomitic seeds. The fertilization-independent seed2 (fis2), fertilization-independent endosperm (fie) and medea (mea) mutants initiate seed development with generation of a free-nuclear endosperm, seed coat development and partial embryogenesis in the absence of fertilization, displaying a maternal-seed abortion phenotype (Ohad et al., 1996; Chaudhury et al., 1997; Grossniklaus et al., 1998; Luo et al., 1999; Ohad et al., 1999; Yadegari et al., 2000). MEA and FIE were shown to encode proteins from the polycomb group, characterized as transcriptional gene silencers in Drosophila melanogaster, whereas F/S encodes a zinc finger protein (Grossniklaus et al., 1998; Kiyosue et al., 1999). The products of these genes are thought to form a complex that represses the genes involved in seed development (Chaudhury et al., 1997). Embryo lethality was shown to be independent of the paternal contribution and gene dosage in mea, suggesting that parent-of-origin effects are involved in the control of seed development (Grossniklaus et al., 1998). After fertilization all the paternal genome would be transiently silenced and embryogenesis and endosperm development would be under the exclusive control of maternal genes (Vielle-Calzada etal., 1999). However, an alternative theory suggests that genomic imprinting may be established not only by modification of DNA methylation but can also be controlled by maternal gametophyte-specific gene activation, dependent on a DNA glycosylase gene, DEMETER (DME) (Choi et al., 2002; 
Kinoshita et al., 2004). These results suggest that developmental pathways leading to asexual and sexual reproduction are interconnected and thus apomixis could be considered a deregulation of the sexual process in both time and space (Koltunow and Grossniklaus, 2003).

\section{Conclusions}

Plant male and female gametophytes and tissues interact to produce a viable embryo, in processes which are mechanically simple, but are based on sophisticated cellular and molecular interactions. All these events seem to rely on unique "decisions" that arise from primary interactions through cell walls with different intrinsic properties and represent the outcome of a rigorous regulated cell-to-cell communication process that should be endowed of some specificity and have a proper genetic specification. Both gametophytes and pistil show developmental programs that prepare these tissues for their future interactions. When first released from the sporophyte, the male gametophyte is already committed to a role, which involves challenging with cues and signaling molecules towards which it should be competent to respond. Yet, besides this generalistic pre-programming, easily evoked by in vitro culture, various mechanisms that happen during interaction with the female tissues provide species and individual specificity. The fact that pollen tubes grow so fast and are so easy to cultivate, makes them specially well adapted models for cellular polarization and morphogenesis studies. The female tissues form a long and complex pathway, branded by different molecular and cellular contexts that presumably are the source of multiple signals that must correctly encode the necessary information for the pollen tube to achieve guidance and correctly target the ovule. Sperm cells are then released on the female gametophyte, where specific molecular and signal interactions constitute the final checkpoint and assure that an appropriate genetic fusion product is formed, triggering a concerted developmental pathway that supports the success of a new generation and the closing of the plant life cycle.

\section{Acknowledgements}

JAFlab is supported by FCT grants POCTI/BCI/41725/2001, POCTI/BCI/ 46453/2002, POCTI/BIA-BCM/60046/2004 and POCTI/BIA-BCM/61270/ 2004. We thank Ana Catarina Certal, Sofia Cordeiro and Nuno Moreno for Fig. $2 A$ and Anne-Frédérique Antoine for Fig. $5 E$.

\section{References}

ALLWOOD, E.G., ANTHONY, R.G., SMERTENKO, A.P., REICHELT, S., DROBAK, B.K., DOONAN, J.H., WEEDS, A.G. and HUSSEY, P.J. (2002). Regulation of the pollen-specific actin-depolymerizing factor LIADF1. Plant Cell 14: 2915-2927.

AMICI, G.B. (1824). Observations microscopiques sur diverse espèces de plantes. Ann. Sci. Nat. Bot. 2: 41-70, 211-248.

AMICI, G.B. (1830). Note sur le mode d'action du pollen sur le stigmate. Extrait d'une lettre d'Amici à Mirbel. Ann. Sci. Nat. Bot. 21: 239-332.

AMICI, G.B. (1847). Sur la fécondation des Orchidées. Ann. Sci. Nat. Bot. 7/8: 193-205.

AN, Y.Q., MCDOWELL, J.M., HUANG, S.R., MCKINNEY, E.C., CHAMBLISS, S. and MEAGHER, R.B. (1996). Strong, constitutive expression of the Arabidopsis ACT2/ ACT8 actin subclass in vegetative tissues. Plant $J$ 10: 107-121.

ANTOINE, A.F., FAURE, J.E., CORDEIRO, S., DUMAS, C., ROUGIER, M. and FEIJO, J.A. (2000). A calcium influx is triggered and propagates in the zygote as a wavefront during in vitro fertilization of flowering plants. Proc. Natt. Acad. Sci. USA97: 1064310648.

ANTOINE, A.F., FAURE, J.E., DUMAS, C. and FEIJO, J.A. (2001). Differential contribution of cytoplasmic $\mathrm{Ca} 2+$ and $\mathrm{Ca} 2+$ influx to gamete fusion and egg activation in maize. Nat Cel/ Biol 3: 1120-3.

ARIIZUMI, T., HATAKEYAMA, K., HINATA, K., SATO, S., KATO, T., TABATA, S. and TORIYAMA, K. (2003). A novel male-sterile mutant of Arabidopsis thaliana, faceless pollen-1, produces pollen with a smooth surface and an acetolysissensitive exine. Plant Mol Biol 53: 107-16.

BAKER, S.C., ROBINSON-BEERS, K., VILLANUEVA, J.M., GAISER, J.C. and GASSER, C.S. (1997). Interactions among genes regulating ovule development in Arabidopsis thaliana. Genetics 145: 1109-24.

BENKERT, R., OBERMEYER, G. and BENTRUP, F.W. (1997). The turgor pressure of growing lily pollen tubes. Protoplasma 198: 1-8.

BOSCH, M., DERKSEN, J. and MARIANI, C. (2003). A functional study of stylar hydroxyproline-rich glycoproteins during pollen tube growth. Sex Plant Reprod 16: 87-98.

BOSCH, M., KNUDSEN, J.S., DERKSEN, J. and MARIANI, C. (2001). Class III pistilspecific extensin-like proteins from tobacco have characteristics of arabinogalactan proteins. Plant Physiol 125: 2180-2188.

BREWBAKER, J.L. and KWACK, B.H. (1963). The essential role of calcium ion in pollen germination and pollen tube growth. Am J Bot 50: 859-865.

BROWN, R.C. (1833). On the organs and mode of fecundation in Orchideae and Asclepideae. Trans. Linn. Soc. London 16: 685-745.

CAI, G., MOSCATELLI, A., DELCASINO, C. and CRESTI, M. (1996). Cytoplasmic motors and pollen tube growth. Sex Plant Reprod 9: 59-64.

CAMACHO, L. and MALHO, R. (2003). Endo/exocytosis in the pollen tube apex is differentially regulated by $\mathrm{Ca} 2+$ and GTPases. J Exp Bot 54: 83-92.

CARPITA, N.C. and GIBEAUT, D.M. (1993). Structural models of primary cell walls in flowering plants: consistency of molecular structure with the physical properties of the walls during growth. Plant $J 3: 1-30$.

CASSAB, G.I. (1998). Plant cell wall proteins. Annu Rev Plant Phys 49: 281-309.

CHAUDHURY, A.M., MING, L., MILLER, C., CRAIG, S., DENNIS, E.S. and PEACOCK, W.J. (1997). Fertilization-independent seed development in Arabidopsis thaliana. Proc Natl Acad Sci USA 94: 4223-8.

CHEN, C.Y., WONG, E.I., VIDALI, L., ESTAVILLO, A., HEPLER, P.K., WU, H.M. and CHEUNG, A.Y. (2002). The regulation of actin organization by actin-depolymerizing factor in elongating pollen tubes. Plant Cell 14: 2175-90.

CHEN, C.Y.H., CHEUNG, A.Y. and WU, H.M. (2003). Actin-depolymerizing factor mediates Rac/Rop GTPase-regulated pollen tube growth. Plant Cel/ 15: 237-249.

CHEN, Y.F., MATSUBAYASHI, Y. and SAKAGAMI, Y. (2000). Peptide growth factor phytosulfokine-alpha contributes to the pollen population effect. Planta 211: 752-

CHEUNG, A.Y. (1996a). The pollen tube growth pathway: Its molecular and biochemical contributions and responses to pollination. Sex Plant Reprod 9: 330-336.

CHEUNG, A.Y. (1996b). Pollen-pistil interactions during pollen-tube growth. Trends Plant SCi 1: 45-51.

CHEUNG, A.Y., CHEN, C.Y., GLAVEN, R.H., DE GRAAF, B.H., VIDALI, L., HEPLER, P.K. and WU, H.M. (2002). Rab2 GTPase regulates vesicle trafficking between the endoplasmic reticulum and the Golgi bodies and is important to pollen tube growth. Plant Cell 14: 945-62.

CHEUNG, A.Y., CHEN, C.Y.H., TAO, L.Z. andREYEVA, T., TWELL, D. and WU, H.M. (2003). Regulation of pollen tube growth by Rac-like GTPases. J Exp Bot 54: 7381.

CHEUNG, A.Y., WANG, H. and WU, H.M. (1995). A floral transmitting tissue-specific glycoprotein attracts pollen tubes and stimulates their growth. Cell 82: 383-93.

CHEUNG, A.Y. and WU, H.M. (2001). Plant biology. Pollen tube guidance-right on target. Science 293: 1441-2.

CHEUNG, A.Y. and WU, H.M. (2004). Overexpression of an Arabidopsis formin stimulates supernumerary actin cable formation from pollen tube cell membrane. Plant Cell 16: 257-269.

CHOI, Y., GEHRING, M., JOHNSON, L., HANNON, M., HARADA, J.J., GOLDBERG, R.B., JACOBSEN, S.E. and FISCHER, R.L. (2002). DEMETER, a DNA glycosylase domain protein, is required for endosperm gene imprinting and seed viability in Arabidopsis. Cell 110: 33-42.

CHRISTENSEN, C.A., GORSICH, S.W., BROWN, R.H., JONES, L.G., BROWN, J., SHAW, J.M. and DREWS, G.N. (2002). Mitochondrial GFA2 is required for synergid cell death in Arabidopsis. Plant Cell 14: 2215-2232. 
CLARKE, A.E. and KNOX, R.B. (1979). Plants and immunity. Dev Comp Immuno/ 3: 571-89.

COSGROVE, D.J., BEDINGER, P. and DURACHKO, D.M. (1997). Group I allergens of grass pollen as cell wall-loosening agents. Proc. Natl. Acad. Sci. USA94:65596564

CRESTI, M., KEIJZER, C.J., TIEZZI, A., CIAMPOLINI, F. and FOCARDI, S. (1986). Stigma of Nicotiana: ultrastructure and biochemical studies. Am J Bot 73: 17131722.

CRESTI, M. and LINSKENS, H.F. (1999). The discovery of sexual reproduction in higher plants. Acta Biol. Crac. Ser. Bot. 41: 19-29.

CRESTI, M., PACINI, E., CIAMPOLINI, F. and SARFATTI, G. (1977). Germination and early tube development in vitro of Licopersicum peruvianum pollen: Ultrastructural features. Planta 136: 239-247.

CRICK, F. (1970). Diffusion in embryogenesis. Nature 5231: 420-2.

CRUZ-GARCIA, F., HANCOCK, C.N. and MCCLURE, B. (2003). S-RNase complexes and pollen rejection. J. Exp. Bot. 54: 123-130.

DARWIN, C. (1862). Fertilization of orchids by insects. Murray, J. London. p. 15.

DE GRAAF, B.H., KNUIMAN, B.A., DERKSEN, J. and MARIANI, C. (2003). Characterization and localization of the transmitting tissue-specific PELPIII proteins of Nicotiana tabacum. J Exp Bot 54: 55-63.

DE GRAAF, B.H.J., DERKSEN, J.W.M. and MARIANI, C. (2001). Pollen and pistil in the progamic phase. Sex Plant Reprod 14: 41-55.

DE GRAAF, B.H.J., KNUIMAN, B.A., VAN DER WEERDEN, G.M., FERON, R., DERKSEN, J. and MARIANI, C. (2004). The PELPIII glycoproteins in Solanaceae : stylar expression and transfer into pollen tube walls. Sex Plant Reprod 16: 245252.

DEARNALEY, J.D.W. and DAGGARD, G.A. (2001). Expression of a polygalacturonase enzyme in germinating pollen in Brassica napus. Sex. Plant Reprod. 13: 265-271.

DERKSEN, J., RUTTEN, T., VANAMSTEL, T., DEWIN, A., DORIS, F. and STEER, M. (1995). Regulation of Pollen-Tube Growth. Acta Bot Neerl 44: 93-119.

DIXIT, R., RIZZO, C., NASRALLAH, M. and NASRALLAH, J. (2001). The Brassica MIP-MOD gene encodes a functional water channel that is expressed in the stigma epidermis. Plant Mol Biol 45: 51-62.

DOBLIN, M.S., DE MELIS, L., NEWBIGIN, E., BACIC, A. and READ, S.M. (2001). Pollen tubes of Nicotiana alata express two genes from different beta-glucan synthase families. Plant Physiol 125: 2040-52.

DOUGHTY, J., HEDDERSON, F., MCCUBBIN, A. and DICKINSON, H. (1993). Interaction between a coating-borne peptide of the Brassica pollen grain and stigmatic $\mathrm{S}$ (self-incompatibility)-locus-specific glycoproteins. Proc Nat/ $\mathrm{Acad} \mathrm{SC}$ USA 90: 467-71.

DOUGHTY, J., WONG, H.Y. and DICKINSON, H.G. (2000). Cysteine-rich pollen coat proteins (PCPS) and their interactions with stigmatic $S$ (incompatibility) and Srelated proteins in Brassica: Putative roles in SI and pollination. Ann Bot-London 85: $161-169$

DUTTA, R. and ROBINSON, K.R. (2004). Identification and characterization of stretch-activated ion channels in pollen protoplasts. Plant Physiol.

EDLUND, A.F., SWANSON, R. and PREUSS, D. (2004). Pollen and stigma structure and function: The role of diversity in pollination. Plant Cell 16.

ELLEMAN, C.J., FRANKLIN-TONG, N.V. and DICKINSON, H.G. (1992). Pollination in species with dry stigmas: The nature os the early stigmatic response and the pathway taken by pollen tubes. New Phytol 121: 413-424.

ENTANI, T., IWANO, M., SHIBA, H., CHE, F.S., ISOGAI, A. and TAKAYAMA, S. (2003). Comparative analysis of the self-incompatibility (S-) locus region of Prunus mume : identification of a pollen-expressed F-box gene with allelic diversity. Genes Cells 8: 203-13

FAURE, J.E., DIGONNET, C., MOL, R., MATTHYSROCHON, E. and DUMAS, C. (1994). In vitro pollination and fertilization in maize (Zea mays L) - Technical procedures and prospects for the dissection of the double fertilization process. Plant Sci. 104: 1-10.

FAURE, J.E., ROTMAN, N., FORTUNE, P. and DUMAS, C. (2002). Fertilization in Arabidopsis thaliana wild type: developmental stages and time course. Plant J30: 481-8.

FAURE, J.E., RUSCHE, M.L., THOMAS, A., KEIM, P., DUMAS, C., MOGENSEN, H.L., ROUGIER, M. and CHABOUD, A. (2003). Double fertilization in maize: the two male gametes from a pollen grain have the ability to fuse with egg cells. Plant J 33: 1051-62.

FEIJO, J.A. (1995). A contribution to the study of sexual plant reproduction in Ophrys lutea (ed. Lisboa: U. Lisboa)

FEIJO, J.A., COSTA, S.S., PRADO, A.M., BECKER, J.D. and CERTAL, A.C. (2004). Signalling by tips. Curr Opin Plant Biol 7: 589-98.

FEIJO, J.A., MALHO, R. and OBERMEYER, G. (1995). Ion dynamics and its possible role during in vitro pollen germination and tube growth. Protoplasma 187: 155-167.

FEIJO, J.A. and MORENO, N. (2004). Imaging plant cells by two-photon excitation. Protoplasma 223: 1-32.

FEIJO, J.A., SAINHAS, J., HACKETT, G.R., KUNKEL, J.G. and HEPLER, P.K. (1999). Growing pollen tubes possess a constitutive alkaline band in the clear zone and growth-dependent acidic tip. J Cell Biol 144: 483-96.

FEIJO, J.A., SAINHAS, J., HOLDAWAY-CLARKE, T., CORDEIRO, M.S., KUNKEL, J.G. and HEPLER, P.K. (2001). Cellular oscillations and the regulation of growth: the pollen tube paradigm. Bioessays 23: 86-94.

FERGUSON, C., TEERI, T.T., SIIKA-AHO, M., READ, S.M. and BACIC, A. (1998). Location of cellulose and callose in pollen tubes and grains of Nicotiana tabacum. Planta 206: 452-460.

FIEBIG, A., KIMPORT, R. and PREUSS, D. (2004). Comparisons of pollen coat genes across Brassicaceae species reveal rapid evolution by repeat expansion and diversification. Proc Nat/ Acad Sci USA 101: 3286-91.

FRANKLIN-TONG, V.E. (1999). Signaling in pollination. Curr Opin Plant Bio/ 2: 490495.

FRANKLIN-TONG, V.E., ATWAL, K.K., HOWELL, E.C., LAWRENCE, M.J. and FRANKLIN, F.C.H. (1991). Self-incompatibility in Papaver rhoeas - There is no evidence for the involvement of stigmatic ribonuclease-activity. Plant Cel/ Environ 14: 423-429.

FRANKLIN-TONG, V.E. and FRANKLIN, F.C.H. (2003). The different mechanisms of gametophytic self-incompatibility. Philos. Trans. R. Soc. Lond. Ser. B-Biol. Sci. 358: 1025-1032.

FRANKLIN-TONG, V.E., HOLDAWAY-CLARKE, T.L., STRAATMAN, K.R., KUNKEL, J.G. and HEPLER, P.K. (2002). Involvement of extracellular calcium influx in the self-incompatibility response of Papaver rhoeas. Plant $J$ 29: 333-45.

FRIEDMAN, W.E. (1995). Organismal duplication, inclusive fitness'theory and altruism: understanding the evolution of endosperm and the angiosperm reproductive syndrome. Proc Natl Acad Sci USA 92: 3913-7.

FRIEDMAN, W.E. (1999). Expression of the cell cycle in sperm of Arabidopsis : implications for understanding patterns of gametogenesis and fertilization in plants and other eukaryotes. Development 126: 1065-75.

FRIEDMAN, W.E. (2001). Developmental and evolutionary hypotheses for the origin of double fertilization and endosperm. C R Acad Sci III 324: 559-67.

FRIEDMAN, W.E. and WILLIAMS, J.H. (2004). Developmental evolution of the sexual process in ancient flowering plant lineages. Plant Cell 16 Suppl: S119-32.

FU, Y., WU, G. and YANG, Z. (2001). Rop GTPase-dependent dynamics of tip-localized F-actin controls tip growth in pollen tubes. J Cell Biol 152: 1019-32.

GASSER, C.S. and ROBINSON-BEERS, K. (1993). Pistil development. Plant Cel/ 5 : 1231-1239.

GEITMANN, A. and PARRE, E. (2004). The local cytomechanical properties of growing pollen tubes correspond to the axial distribution of structural cellular elements. Sex Plant Reprod 17: 9-16.

GOLDMAN, M.H., GOLDBERG, R.B. and MARIANI, C. (1994). Female sterile tobacco plants are produced by stigma-specific cell ablation. EMBO J 13: 2976-84.

GROSSNIKLAUS, U., VIELLE-CALZADA, J.P., HOEPPNER, M.A. and GAGLIANO, W.B. (1998). Maternal control of embryogenesis by MEDEA, a polycomb group gene in Arabidopsis. Science 280: 446-50.

GU, Y., VERNOUD, V., FU, Y. and YANG, Z.B. (2003). ROP GTPase regulation of pollen tube growth through the dynamics of tip-localized F-actin. J Exp Bot 54: 93101.

GUO, F.Q., OKAMOTO, M. and CRAWFORD, N.M. (2003). Identification of a plant nitric oxide synthase gene involved in hormonal signaling. Science 302: 100-3.

HEPLER, P.K., VIDALI, L. and CHEUNG, A.Y. (2001). Polarized cell growth in higher plants. Annu. Rev. Cell Dev. Biol. 17: 159-187.

HERRERO, M. and DICKINSON, H.G. (1979). Pollen-pistil incompatibility in Petunia 
hybrida: changes in the pistil following compatible and incompatible intraspecific crosses. J Cell Sci 36: 1-18.

HERRERO, M. and HORMAZA, J.I. (1996). Pistil strategies controlling pollen tube growth. Sex Plant Reprod 9: 343-347.

HESLOP-HARRISON, J. (1987). Pollen germination and pollen-tube growth. International Review of Cytology-a Survey of Cell Biology 107: 1-78.

HESLOP-HARRISON, J. and HESLOP-HARRISON, Y. (1986). Pollen-tube chemotropism: fact or delusion? In Biology of Reproduction and Cell Motility in Plants and Animals, (ed. CRESTI, M. and ROMANO, D.). University of Siena, Italy, pp.169174.

HESLOP-HARRISON, Y. and SHIVANNA, K.R. (1977). The receptive surface of the angiosperm stigma. Ann Bot 41: 1233-1258.

HIGASHIYAMA, T., KUROIWA, H., KAWANO, S. and KUROIWA, T. (1997). Kinetics of double fertilization in Torenia fournieri based on direct observations of the naked embryo sac. Planta 203: 101-110.

HIGASHIYAMA, T., KUROIWA, H., KAWANO, S. and KUROIWA, T. (1998). Guidance in vitro of the pollen tube to the naked embryo sac of Torenia fournieri. Plant Cell 10: 2019-32.

HIGASHIYAMA, T., KUROIWA, H., KAWANO, S. and KUROIWA, T. (2000). Explosive discharge of pollen tube contents in Torenia fournieri. Plant Physiol 122: 114.

HIGASHIYAMA, T., KUROIWA, H. and KUROIWA, T. (2003). Pollen-tube guidance: beacons from the female gametophyte. Curr Opin Plant Biol 6: 36-41.

HIGASHIYAMA, T., YABE, S., SASAKI, N., NISHIMURA, Y., MIYAGISHIMA, S., KUROIWA, H. and KUROIWA, T. (2001). Pollen tube attraction by the synergid cell. Science 293: 1480-3.

HISCOCK, S.J., DEWEY, F.M., COLEMAN, J.O.D. and DICKINSON, H.G. (1994). Identification and localization of an active cutinase in the pollen of Brassica napus L. Planta 193: 377-384.

HISCOCK, S.J., DOUGHTY, J., WILLIS, A.C. and DICKINSON, H.G. (1995). A 7-kDa pollen coating-borne peptide from Brassica napus interacts with S-locus glycoprotein and S-locus-related glycoprotein. Planta 196: 367-74.

HOLDAWAY-CLARKE, T.L., FEIJO, J.A., HACKETT, G.R., KUNKEL, J.G. and HEPLER, P.K. (1997). Pollen tube growth and the intracellular cytosolic calcium gradient oscillate in phase while extracellular calcium influx is delayed. Plant Cell 9: 1999-2010.

HOLDAWAY-CLARKE, T.L. and HEPLER, P.K. (2003). Control of pollen tube growth: role of ion gradients and fluxes. New Phytol 159: 539-563.

HOLDAWAY-ClARKE, T.L., WEDDLE, N.M., KIM, S., ROBI, A., PARRIS, C., KUNKEL, J.G. and HEPLER, P.K. (2003). Effect of extracellular calcium, pH and borate on growth oscillations in Lilium formosanum pollen tubes. J Exp Bot 54: 65-72.

HUANG, B.Q., PIERSON, E.S., RUSSELL, S.D., TIEZZI, A. and CRESTI, M. (1993). Cytoskeletal organisation and modification during pollen tube arrival, gamete delivery and fertilisation in Plumbago zeylanica. Zygote 1: 143-54.

HUANG, B.Q. and RUSSELL, S.D. (1992). Synergic degeneration in Nicotiana - a quantitative, fluorochromatic and chlorotetracycline study. Sex Plant Reprod 5: 151-155.

HUANG, B.Q. and RUSSELL, S.D. (1994). Fertlization in Nicotiana tabacum : cytoskeletal modifications in the embryo sac during synergid degeneration. Planta 194: $200-214$

HUANG, S., AN, Y.Q., MCDOWELL, J.M., MCKINNEY, E.C. and MEAGHER, R.B. (1997). The Arabidopsis ACT11 actin gene is strongly expressed in tissues of the emerging inflorescence, pollen and developing ovules. Plant Molec. Biol. 33: 12539.

HUANG, S.R., AN, Y.Q., MCDOWELL, J.M., MCKINNEY, E.C. and MEAGHER, R.B. (1996). The Arabidopsis thaliana ACT4/ACT12 actin gene subclass is strongly expressed throughout pollen development. Plant $J$ 10: 189-202.

HUCK, N., MOORE, J.M., FEDERER, M. and GROSSNIKLAUS, U. (2003). The Arabidopsis mutant feronia disrupts the female gametophytic control of pollen tube reception. Development 130: 2149-59.

HULSKAMP, M., KOPCZAK, S.D., HOREJSI, T.F., KIHL, B.K. and PRUITT, R.E. (1995a). Identification of genes required for pollen-stigma recognition in Arabidopsis thaliana. Plant $J$ 8: 703-14.

HULSKAMP, M., SCHNEITZ, K. and PRUITT, R.E. (1995b). Genetic evidence for a long-range activity that directs pollen tube guidance in Arabidopsis. Plant Cel/ 7: 57-64.

HUSSEY, P.J., ALLWOOD, E.G. and SMERTENKO, A.P. (2002a). Actin-binding proteins in the Arabidopsis genome database: properties of functionally distinct plant actin-depolymerizing factors/cofilins. Philos. Trans. R. Soc. Lond. Ser. B-Biol. Sci. 357: 791-798.

HUSSEY, P.J., HAWKINS, T.J., IGARASHI, H., KALORITI, D. and SMERTENKO, A. (2002b). The plant cytoskeleton: recent advances in the study of the plant microtubule-associated proteins MAP-65, MAP-190 and the Xenopus MAP215-like protein, MOR1. Plant Mol Biol 50: 915-924.

IKEDA, S., NASRALLAH, J.B., DIXIT, R., PREISS, S. and NASRALLAH, M.E. (1997). An aquaporin-like gene required for the Brassica self-incompatibility response. Science 276: 1564-6.

IWANAMI, Y. (1956). Protoplasmic movement in pollen grains and tubes. Phytomorphol 6: 288-295.

JAUH, G.Y., ECKARD, K.J., NOTHNAGEL, E.A. and LORD, E.M. (1997). Adhesion of lily pollen tubes on an artificial matrix. Sex. Plant Reprod. 10: 173-180.

JAUH, G.Y. and LORD, E.M. (1996). Localization of pectins and arabinogalactanproteins in lily (Lilium longiflorum L) pollen tube and style and their possible roles in pollination. Planta 199: 251-261.

JOHNSON, M.A. and PREUSS, D. (2002). Plotting a course: multiple signals guide pollen tubes to their targets. Dev Cel/ 2: 273-81.

JOHNSON, S.A. and MCCORMICK, S. (2001). Pollen germinates precociously in the anthers of raring-to-go, an Arabidopsis gametophytic mutant. Plant Physiol 126: 685-695.

JOOS, U., VANAKEN, J. and KRISTEN, U. (1994). Microtubules are involved in maintaining the cellular polarity in pollen tubes of Nicotiana sy/vestris. Protoplasma 179: 5-15.

KACHROO, A., SCHOPFER, C.R., NASRALLAH, M.E. and NASRALLAH, J.B. (2001). Allele-specific receptor-ligand interactions in Brassica self-incompatibility. Science 293: 1824-6.

KANDASAMY, M.K., MCKINNEY, E.C. and MEAGHER, R.B. (1999). The late pollenspecific actins in angiosperms. Plant $J$ 18: 681-91.

KANDASAMY, M.K., THORSNESS, M.K., RUNDLE, S.J., GOLDBERG, M.L., NASRALLAH, J.B. and NASRALLAH, M.E. (1993). Ablation of papillar cell function in Brassica flowers results in the loss of stigma receptivity to pollination. Plant Cell 5: 263-275.

KAO, T.H. and MCCUBBIN, A.G. (1996). How flowering plants discriminate between self and non-self pollen to prevent inbreeding. Proc Nat/ Acad Sci USA 93: 1205965.

KAO, T.H. and TSUKAMOTO, T. (2004). The molecular and genetic bases of S-RNasebased self-incompatibility. Plant Cel/ 16 Suppl: S72-83.

KIM, H.U., COTTER, R., JOHNSON, S., SENDA, M., DODDS, P., KULIKAUSKA, R., TANG, W., EZCURA, I., HERZMARK, P. and MCCORMICK, S. (2002). New pollenspecific receptor kinases identified in tomato, maize and Arabidopsis : the tomato kinases show overlapping but distinct localization patterns on pollen tubes. Plant Mol Biol 50: 1-16

KIM, S., MOLLET, J.C., DONG, J., ZHANG, K., PARK, S.Y. and LORD, E.M. (2003). Chemocyanin, a small basic protein from the lily stigma, induces pollen tube chemotropism. Proc Natl Acad Sci USA 100: 16125-30.

KIM, S.R., KIM, Y. and AN, G. (1993). Molecular cloning and characterization of antherpreferential cDNA encoding a putative actin-depolymerizing factor. Plant Mol Biol 21: $39-45$.

KINOSHITA, T., MIURA, A., CHOI, Y., KINOSHITA, Y., CAO, X., JACOBSEN, S.E., FISCHER, R.L. and KAKUTANI, T. (2004). One-way control of FWA imprinting in Arabidopsis endosperm by DNA methylation. Science 303: 521-3.

KIYOSUE, T., OHAD, N., YADEGARI, R., HANNON, M., DINNENY, J., WELLS, D., KATZ, A., MARGOSSIAN, L., HARADA, J.J., GOLDBERG, R.B. et al. (1999). Control of fertilization-independent endosperm development by the MEDEA polycomb gene in Arabidopsis. Proc Natl Acad Sci USA 96: 4186-91.

KNOX, R.B. (1984). Pollen-pistil interactions. Springer, New York, Berlin, Heidelberg

KNOX, R.B. and HESLOP-HARRISON, J. (1970). Pollen-wall proteins: localization and enzymic activity. J Cell Sci 6: 1-27.

KNOX, R.B., ZEE, S.Y., BLOMSTEDT, C. and SINGH, M.B. (1993). Male gametes and fertilization in angiosperms. New Phytol. 125: 679-694. 
KOLTUNOW, A.M. and GROSSNIKLAUS, U. (2003). Apomixis: a developmental perspective. Annu Rev Plant Biol 54: 547-74.

KOST, B., LEMICHEZ, E., SPIELHOFER, P., HONG, Y., TOLIAS, K., CARPENTER, C. and CHUA, N.H. (1999). Rac homologues and compartmentalized phosphatidylinositol 4,5-bisphosphate act in a common pathway to regulate polar pollen tube growth. J Cell Biol 145: 317-330.

KRANZ, E. and LORZ, H. (1993). In vitro fertilization with isolated, single gametes results in zygotic embryogenesis and fertile maize plants. Plant Cell 5: 739-746.

KRISHNAKUMAR, S. and OPPENHEIMER, D.G. (1999). Extragenic suppressors of the Arabidopsis zwi-3 mutation identify new genes that function in trichome branch formation and pollen tube growth. Development 126: 3079-88.

LAI, Z., MA, W., HAN, B., LIANG, L., ZHANG, Y., HONG, G. and XUE, Y. (2002). An F-box gene linked to the self-incompatibility (S) locus of Antirrhinum is expressed specifically in pollen and tapetum. Plant Mol Bio/ 50: 29-42.

LALANNE, E., HONYS, D., JOHNSON, A., BORNER, G.H.H., LILLEY, K.S., DUPREE, P., GROSSNIKLAUS, U. and TWELL, D. (2004). SETH1 and SETH2, two components of the glycosylphosphatidylinositol anchor biosynthetic pathway, are required for pollen germination and tube growth in Arabidopsis. Plant Cel/ 16:229240.

LAMATTINA, L., GARCIA-MATA, C., GRAZIANO, M. and PAGNUSSAT, G. (2003). Nitric oxide: the versatility of an extensive signal molecule. Annu Rev PlantBio/54: 109-36.

LANCELLE, S.A. and HEPLER, P.K. (1992). Ultrastructure of freeze-substituted pollen tubes of Lilium longiflorum. Protoplasma 167: 215-230.

LI, H., LIN, Y., HEATH, R.M., ZHU, M.X. and YANG, Z. (1999). Control of pollen tube tip growth by a Rop GTPase-dependent pathway that leads to tip-localized calcium influx. Plant Cell 11: 1731-42.

LI, Y.Q., FALERI, C., GEITMANN, A., ZHANG, H.Q. and CRESTI, M. (1995). Immunogold localization of arabinogalactan proteins, unesterified and esterified pectins in pollen grains and pollen tubes of Nicotiana tabacum L. Protoplasma 189: 26-36.

LI, Y.Q., MARECK, A., FALERI, C., MOSCATELLI, A., LIU, Q. and CRESTI, M. (2002). Detection and localization of pectin methylesterase isoforms in pollen tubes of Nicotiana tabacum L. Planta 214: 734-740.

LI, Y.Q., MOSCATELLI, A., CAI, G. and CRESTI, M. (1997). Functional interactions among cytoskeleton, membranes and cell wall in the pollen tube of flowering plants. Int Rev Cytol 176: 133-99.

LIN, Y. and YANG, Z. (1997). Inhibition of pollen tube elongation by microinjected antiRop1Ps antibodies suggests a crucial role for Rho-type GTPases in the control of tip growth. Plant Cel/ 9: 1647-1659.

LIN, Y.K., WANG, Y.L., ZHU, J.K. and YANG, Z.B. (1996). Localization of a Rho GTPase implies a role in tip growth and movement of the generative cell in pollen tubes. Plant Cell 8: 293-303.

LINDSEY, K., CASSON, S. and CHILLEY, P. (2002). Peptides: new signalling molecules in plants. Trends Plant Sci. 7: 78-83.

LOBSTEIN, E., GUYON, A., FERAULT, M., TWELL, D., PELLETIER, G. and BONHOMME, S. (2004). The putative Arabidopsis homologue of yeast Vps52p is required for pollen tube elongation, localizes to Golgi and might be involved in vesicle trafficking. Plant Physiol 135: 1480-1490.

LOBSTEIN, E., GUYON, A., PROCISSI, A. and BONHOMME, S. (2003). KINKY POLLEN and POKY POLLEN TUBE are two novel genes required for tip growth and duplicated in the Arabidopsis genome. Acta Biol. Crac. Ser. Bot. 45: 125-128.

LOLLE, S.J., BERLYN, G.P., ENGSTROM, E.M., KROLIKOWSKI, K.A., REITER, W.D. and PRUITT, R.E. (1997). Developmental regulation of cell interactions in the Arabidopsis fiddlehead-1 mutant: a role for the epidermal cell wall and cuticle. Dev Biol 189: 311-21.

LOLLE, S.J. and CHEUNG, A.Y. (1993). Promiscuous germination and growth of wildtype pollen from Arabidopsis and related species on the shoot of the Arabidopsis mutant, fiddlehead. Dev Biol 155: 250-8.

LOLLE, S.J., HSU, W. and PRUITT, R.E. (1998). Genetic analysis of organ fusion in Arabidopsis thaliana. Genetics 149: 607-619.

LOLLE, S.J. and PRUITT, R.E. (1999). Epidermal cell interactions: a case for local talk. Trends Plant Sci 4: 14-20.

LOPEZ, I., ANTHONY, R.G., MACIVER, S.K., JIANG, C.J., KHAN, S., WEEDS, A.G. and HUSSEY, P.J. (1996). Pollen specific expression of maize genes encoding actin depolymerizing factor-like proteins. Proc. Nat/Acad SciUSA 93: 7415-7420.
LORD, E.M. (2003). Adhesion and guidance in compatible pollination. J Exp Bot 54: 47-54.

LORD, E.M. and SANDERS, L.C. (1992). Roles for the extracellular matrix in plant development and pollination: a special case of cell movement in plants. Dev Biol 153: 16-28.

LUO, M., BILODEAU, P., KOLTUNOW, A., DENNIS, E.S., PEACOCK, W.J. and CHAUDHURY, A.M. (1999). Genes controlling fertilization-independent seed development in Arabidopsis thaliana. Proc Nat/ Acad Sci USA 96: 296-301.

LUSH, W.M. (1999). Whither chemotropism and pollen tube guidance? Trends Plant Sci 4: 413-418.

LUSH, W.M., GRIESER, F. and WOLTERS-ARTS, M. (1998). Directional guidance of Nicotiana alata pollen tubes in vitro and on the stigma. Plant Physiol 118: 733-41.

LUU, D.T., HEIZMANN, P. and DUMAS, C. (1997a). Pollen-stigma adhesion in kale is not dependent on the self-(in)compatibility genotype. Plant Physiol 115: 12211230.

LUU, D.T., HEIZMANN, P., DUMAS, C., TRICK, M. and CAPPADOCIA, M. (1997b). Involvement of $S L R 1$ genes in pollen adhesion to the stigmatic surface in Brassica. Sex Plant Reprod 10: 227-235.

LUU, D.T., MARTY-MAZARS, D., TRICK, M., DUMAS, C. and HEIZMANN, P. (1999). Pollen-stigma adhesion in Brassica spp involves SLG and SLR1 glycoproteins. Plant Cell 11: 251-62.

LUU, D.T., QIN, X., LAUBLIN, G., YANG, Q., MORSE, D. and CAPPADOCIA, M. (2001). Rejection of S-heteroallelic pollen by a dual-specific s-RNase in Solanum chacoense predicts a multimeric SI pollen component. Genetics 159: 329-35.

LUU, D.T., QIN, X., MORSE, D. and CAPPADOCIA, M. (2000). S-RNase uptake by compatible pollen tubes in gametophytic self-incompatibility. Nature 407: 649-51.

MAHESHWARI, P. (1950). McGraw-Hill, New York.

MALHO, R. and TREWAVAS, A.J. (1996). Localized apical increases of cytosolic free calcium control pollen tube orientation. Plant Cell 8: 1935-1949.

MARTON, M.L., CORDTS, S., BROADHVEST, J. and DRESSELHAUS, T. (2005). Micropylar pollen tube guidance by egg apparatus 1 of maize. Science $307: 573$

MASCARENHAS, J.P. (1975). The biochemistry of angiosperm pollen development. Bot Rev 41: 259-314.

MASCARENHAS, J.P. (1993). Molecular mechanisms of pollen tube growth and differentiation. Plant Cel/ 5: 1303-1314.

MATSUBAYASHI, Y., YANG, H. and SAKAGAMI, Y. (2001). Peptide signals and their receptors in higher plants. Trends Plant Sci 6: 573-7.

MAYFIELD, J.A., FIEBIG, A., JOHNSTONE, S.E. and PREUSS, D. (2001). Gene families from the Arabidopsis thaliana pollen coat proteome. Science 292: 2482-

MAZINA, S.E., MATVEEVA, N.P. and ERMAKOV, I.P. (2002). Determination of a position of a functional pore in the tobacco pollen. Tsitologiia 44: 33-9.

MCCORMICK, S. (2004). Control of male gametophyte development. Plant Cell 16 Suppl: S142-53.

MCKENNA, S.T., VIDALI, L. and HEPLER, P.K. (2004). Profilin inhibits pollen tube growth through actin-binding, but not poly- I-proline-binding. Planta.

MESSERLI, M. and ROBINSON, K.R. (1997). Tip localized Ca2+ pulses are coincident with peak pulsatile growth rates in pollen tubes of Lilium longiflorum. J Cel/ Sci 110 (Pt 11): 1269-78.

MILLER, D.D., CALLAHAM, D.A., GROSS, D.J. and HEPLER, P.K. (1992). Free Ca2+ gradient in growing pollen tubes of Lilium. J. Cell SCi. 101: 7-12.

MILLER, D.D., LANCELLE, S.A. and HEPLER, P.K. (1996). Actin microfilaments do not form a dense meshwork in Lilium longiflorum pollen tube tips. Protoplasma 195: 123-132.

MOL, R., IDZIKOWSKA, K., DUMAS, C. and MATTHYS-ROCHON, E. (2000). Late steps of egg cell differentiation are accelerated by pollination in Zea mays L. Planta 210: 749-57.

MOLLET, J.C., KIM, S., JAUH, G.Y. and LORD, E.M. (2002). Arabinogalactan proteins, pollen tube growth and the reversible effects of Yariv phenylglycoside. Protoplasma 219: 89-98.

MOLLET, J.C., PARK, S.Y., NOTHNAGEL, E.A. and LORD, E.M. (2000). A lily stylar pectin is necessary for pollen tube adhesion to an in vitro stylar matrix. Plant Cell 12: $1737-50$ 
MOULINE, K., VERY, A.A., GAYMARD, F., BOUCHEREZ, J., PILOT, G., DEVIC, M., BOUCHEZ, D., THIBAUD, J.B. and SENTENAC, H. (2002). Pollen tube development and competitive ability are impaired by disruption of a Shaker $\mathrm{K}+$ channel in Arabidopsis. Genes Dev 16: 339-50.

MU, J.H., LEE, H.S. and KAO, T.H. (1994a). Characterization of a pollen-expressed receptor-like kinase gene of Petunia inflata and the activity of its encoded kinase. Plant Cell 6: 709-21.

MU, J.H., STAINS, J.P. and KAO, T. (1994b). Characterization of a pollen-expressed gene encoding a putative pectin esterase of Petunia inflata. Plant Mol Biol 25: 53944.

MULCAHY, G.B. and MULCAHY, D.L. (1987). Induced pollen directionality. Am J Bot 74: 1458-1459.

MUSCHIETTI, J., EYAL, Y. and MCCORMICK, S. (1998). Pollen tube localization implies a role in pollen-pistil interactions for the tomato receptor-like protein kinases LePRK1 and LePRK2. Plant Cel/ 10: 319-30.

OHAD, N., MARGOSSIAN, L., HSU, Y.C., WILLIAMS, C., REPETTI, P. and FISCHER, R.L. (1996). A mutation that allows endosperm development without fertilization. Proc Natl Acad Sci USA 93: 5319-24.

OHAD, N., YADEGARI, R., MARGOSSIAN, L., HANNON, M., MICHAELI, D., HARADA, J.J., GOLDBERG, R.B. and FISCHER, R.L. (1999). Mutations in FIE, a WD polycomb group gene, allow endosperm development without fertilization. Plant Cell 11: 407-16.

O'NEILL, S.D., NADEAU, J.A., ZHANG, X.S., BUI, A.Q. and HALEVY, A.H. (1993) Interorgan regulation of ethylene biosynthetic genes by pollination. Plant Cell 5: 419-32.

PALANIVELU, R., BRASS, L., EDLUND, A.F. and PREUSS, D. (2003). Pollen tube growth and guidance is regulated by $P O P 2$, an Arabidopsis gene that controls GABA levels. Cell 114: 47-59.

PARK, S.Y., JAUH, G.Y., MOLLET, J.C., ECKARD, K.J., NOTHNAGEL, E.A., WALLING, L.L. and LORD, E.M. (2000). A lipid transfer-like protein is necessary for lily pollen tube adhesion to an in vitro stylar matrix. Plant Cel/ 12: 151-163.

PARK, S.Y. and LORD, E.M. (2003). Expression studies of SCA in lily and confirmation of its role in pollen tube adhesion. Plant Mol Biol 51: 183-9.

PARTON, R.M., FISCHER-PARTON, S., TREWAVAS, A.J. and WATAHIKI, M.K. (2003). Pollen tubes exhibit regular periodic membrane trafficking events in the absence of apical extension. J Cel/ Sci 116: 2707-19.

PARTON, R.M., FISCHER-PARTON, S., WATAHIKI, M.K. and TREWAVAS, A.J. (2001). Dynamics of the apical vesicle accumulation and the rate of growth are related in individual pollen tubes. J Cell Sci 114: 2685-95.

PAXSON-SOWDERS, D.M., DODRILL, C.H., OWEN, H.A. and MAKAROFF, C.A. (2001). DEX1, a novel plant protein, is required for exine pattern formation during pollen development in Arabidopsis. Plant Physiol 127: 1739-49.

PICTON, J.M. and STEER, M.W. (1981). Determination of secretory vesicle production rates by dictyosomes in pollen tubes of Tradescantia using cytochalasin D. $\mathrm{J} \mathrm{Cell}$ Sci 49: 261-72.

PICTON, J.M. and STEER, M.W. (1983). Membrane recycling and the control of secretory activity in pollen tubes. J Cel/ Sci 63: 303-10.

PIERSON, E.S. and CRESTI, M. (1992). Cytoskeleton and cytoplasmic organization of pollen and pollen tubes. Int.Rev.Cytol. 140: 73-125.

PIERSON, E.S., LICHTSCHEIDL, I.K. and DERKSEN, J. (1990). Structure and behaviour of organelles in living pollen tubes of Lilium longiflorum. $J$ Exp Bot 41: 1461-1468.

PIERSON, E.S., MILLER, D.D., CALLAHAM, D.A., VAN AKEN, J., HACKETT, G. and HEPLER, P.K. (1996). Tip-localized calcium entry fluctuates during pollen tube growth. Dev Biol 174: 160-73.

PIFFANELLI, P., ROSS, J.H.E. and MURPHY, D.J. (1998). Biogenesis and function of the lipidic structures of pollen grains. Sex Plant Reprod 11: 65-80.

PRADO, A.M., PORTERFIELD, D.M. and FEIJO, J.A. (2004). Nitric oxide is involved in growth regulation and re-orientation of pollen tubes. Development 131:2707-14.

PREUSS, D., LEMIEUX, B., YEN, G. and DAVIS, R.W. (1993). A conditional sterile mutation eliminates surface components from Arabidopsis pollen and disrupts cell signaling during fertilization. Genes Dev. 7: 974-85.

PROCISSI, A., DE LAISSARDIERE, S., FERAULT, M., VEZON, D., PELLETIER, G. and BONHOMME, S. (2001). Five gametophytic mutations affecting pollen development and pollen tube growth in Arabidopsis thaliana. Genetics 158: 1773-1783.
PROCISSI, A., GUYON, A., PIERSON, E.S., GIRITCH, A., KNUIMAN, B., GRANDJEAN, O., TONELLI, C., DERKSEN, J., PELLETIER, G. and BONHOMME, S. (2003). KINKYPOLLENencodes a SABRE-like protein required for tip growth in Arabidopsis and conserved among eukaryotes. Plant J 36: 894-904.

PRUITT, R.E., VIELLE-CALZADA, J.P., PLOENSE, S.E., GROSSNIKLAUS, U. and LOLLE, S.J. (2000). FIDDLEHEAD, a gene required to suppress epidermal cell interactions in Arabidopsis, encodes a putative lipid biosynthetic enzyme. ProcNat/ Acad Sci USA 97: 1311-6.

QIAO, H., WANG, H., ZHAO, L., ZHOU, J., HUANG, J., ZHANG, Y. and XUE, Y. (2004). The F-box protein AhSLF-S2 physically interacts with S-RNases that may be inhibited by the ubiquitin/26S proteasome pathway of protein degradation during compatible pollination in Antirrhinum. Plant Cell 16: 582-95.

RAGHAVAN, V. (2003). Some reflections on double fertilization, from its discovery to the present. New Phytologist 159: 565-583.

RATHORE, K.S., CORK, R.J. and ROBINSON, K.R. (1991). A cytoplasmic gradient of $\mathrm{Ca} 2+$ is correlated with the growth of lily pollen tubes. Dev Biol 148: 612-9.

RAY, S.M., PARK, S.S. and RAY, A. (1997). Pollen tube guidance by the female gametophyte. Development 124: 2489-98.

REGER, B.J., CHAUBAL, R. and PRESSEY, R. (1992). Chemotropic responses by pearl millet pollen tubes. Sex. Plant Reprod. 5: 47-56.

RODRIGUEZ-GARCIA, M.I., ALAOUI, M.M., DIAZ, J.D. and FERNANDEZ, M.D. (2003). Observations on microtubules and nuclei motility in the pollen tube of olive (Olea europaea L.). Acta Biol Cracov Bot 45: 97-101.

ROTMAN, N., ROZIER, F., BOAVIDA, L., DUMAS, C., BERGER, F. and FAURE, J.E. (2003). Female control of male gamete delivery during fertilization in Arabidopsis thaliana. Curr Biol 13: 432-6.

ROY, S., JAUH, G.Y., HEPLER, P.K. and LORD, E.M. (1998). Effects of Yariv phenylglycoside on cell wall assembly in the lily pollen tube. Planta 204: 450-458.

RUBINSTEIN, A.L., BROADWATER, A.H., LOWREY, K.B. and BEDINGER, P.A. (1995). Pex1, a pollen-specific gene with an extensin-like domain. Proc Nat/ Acad Sci USA 92: 3086-90.

RUITER, R.K., VANELDIK, G.J., VANHERPEN, M.M.A., SCHRAUWEN, J.A.M. and WULLEMS, G.J. (1997). Expression in anthers of two genes encoding Brassica oleracea transmembrane channel proteins. Plant Mol. Biol. 34: 163-168.

RUSSELL, S.D. (1985). Preferential fertilization in Plumbago: ultrastructural evidence for gamete level recognition in an angiosperm. Proc Nat/Acad Sci USA 82: 61296132.

RUSSELL, S.D. (1992). Double fertilization. Int Rev Cytol 140: 357-388.

SANDERS, L.C. and LORD, E.M. (1992). The extracellularmatrix inpollen tube growth. Springer-Verlag, New York.

SCHIOTT, M., ROMANOWSKY, S.M., BAEKGAARD, L., JAKOBSEN, M.K., PALMGREN, M.G. and HARPER, J.F. (2004). A plant plasma membrane Ca2+ pump is required for normal pollen tube growth and fertilization. Proc Nat/Acad Sci USA 101: 9502-7.

SCHOPFER, C.R., NASRALLAH, M.E. and NASRALLAH, J.B. (1999). The male determinant of self-incompatibility in Brassica. Science 286: 1697-700.

SHIBA, H., TAKAYAMA, S., IWANO, M., SHIMOSATO, H., FUNATO, M., NAKAGAWA, T., CHE, F.S., SUZUKI, G., WATANABE, M., HINATA, K. etal. (2001). A pollen coat protein, SP11/SCR, determines the pollen S-specificity in the self-incompatibility of Brassica species. Plant Physiol 125: 2095-103.

SHIMIZU, K.K. and OKADA, K. (2000). Attractive and repulsive interactions between female and male gametophytes in Arabidopsis pollen tube guidance. Development 127: $4511-8$

SHOWALTER, A.M. (2001). Arabinogalactan-proteins: structure, expression and function. Cell Mol Life Sci 58: 1399-1417.

SIJACIC, P., WANG, X., SKIRPAN, A.L., WANG, Y., DOWD, P.E., MCCUBBIN, A.G., HUANG, S. and KAO, T.H. (2004). Identification of the pollen determinant of $S$ RNase-mediated self-incompatibility. Nature 429: 302-5.

SKIRPAN, A.L., MCCUBBIN, A.G., ISHIMIZU, T., WANG, X., HU, Y., DOWD, P.E., MA, $\mathrm{H}$. and $\mathrm{KAO}, \mathrm{T}$. (2001). Isolation and characterization of kinase interacting protein 1 , a pollen protein that interacts with the kinase domain of PRK1, a receptor-like kinase of petunia. Plant Physiol 126: 1480-92.

SMERTENKO, A.P., ALLWOOD, E.G., KHAN, S., JIANG, C.J., MACIVER, S.K., WEEDS, A.G. and HUSSEY, P.J. (2001). Interaction of pollen-specific actindepolymerizing factor with actin. Plant $J$ 25: 203-12. 
SNOWMAN, B.N., GEITMANN, A., CLARKE, S.R., STAIGER, C.J., FRANKLIN, F.C.H., EMONS, A.M.C. and FRANKLIN-TONG, V.E. (2000). Signalling and the cytoskeleton of pollen tubes of Papaver rhoeas. Ann Bot-London 85: 49-57.

SOMMER-KNUDSEN, J., LUSH, W.M., BACIC, A. and CLARKE, A.E. (1998). Reevaluation of the role of a transmitting tract-specific glycoprotein on pollen tube growth. Plant J 13: 529-535.

SORRI, O., ASTROM, H. and RAUDASKOSKI, M. (1996). Actin and tubulin expression and isotype pattern during tobacco pollen tube growth. Sex Plant Reprod 9: 255263.

STAIGER, C.J., GOODBODY, K.C., HUSSEY, P.J., VALENTA, R., DROBAK, B.K. and LLOYD, C.W. (1993). The profilin multigene family of maize: differential expression of three isoforms. Plant J. 4: 631-41.

STEER, M.W. and STEER, J.M. (1989). Pollen tube tip growth. New Phyto/ 111: 323358.

STRATFORD, S., BARNES, W., HOHORST, D.L., SAGERT, J.G., COTTER, R., GOLUBIEWSKI, A., SHOWALTER, A.M., MCCORMICK, S. and BEDINGER, $P$ (2001). A leucine-rich repeat region is conserved in pollen extensin-like (Pex) proteins in monocots and dicots. Plant Mol Biol 46: 43-56.

TAKAYAMA, S. and ISOGAI, A. (2003). Molecular mechanism of-self-recognition in Brassica self-incompatibility. J. Exp. Botany 54: 149-156.

TAKAYAMA, S., SHIBA, H., IWANO, M., ASANO, K., HARA, M., CHE, F.S., WATANABE, M., HINATA, K. and ISOGAI, A. (2000). Isolation and characterization of pollen coat proteins of Brassica campestris that interact with S locus-related glycoprotein 1 involved in pollen-stigma adhesion. Proc Nat/ Acad Sci USA 97: 3765-70.

TAKAYAMA, S., SHIMOSATO, H., SHIBA, H., FUNATO, M., CHE, F.S., WATANABE, M., IWANO, M. and ISOGAI, A. (2001). Direct ligand-receptor complex interaction controls Brassica self-incompatibility. Nature 413: 534-8.

TAKEDA, H., YOSHIKAWA, T., LIU, X.Z., NAKAGAWA, N., LI, Y.Q. and SAKURAI, N. (2004). Molecular cloning of two exo-beta-glucanases and their in vivo substrates in the cell walls of lily pollen tubes. Plant Cell Physiol 45: 436-44.

TANG, W., KELLEY, D., EZCURRA, I., COTTER, R. and MCCORMICK, S. (2004). LeSTIG1, an extracellular binding partner for the pollen receptor kinases LePRK1 and LePRK2, promotes pollen tube growth in vitro. Plant $J$ 39: 343-53.

TANG, W.H., EZCURRA, I., MUSCHIETTI, J. and MCCORMICK, S. (2002). A cysteinerich extracellular protein, LAT52, interacts with the extracellular domain of the pollen receptor kinase LePRK2. Plant Cell 14: 2277-2287.

TAYLOR, P.E., GLOVER, J.A., LAVITHIS, M., CRAIG, S., SINGH, M.B., KNOX, R.B., DENNIS, E.S. and CHAUDHURY, A.M. (1998). Genetic control of male fertility in Arabidopsis thaliana: structural analyses of postmeiotic developmental mutants. Planta 205: 492-505.

THANGAVELU, M., BELOSTOTSKY, D., BEVAN, M.W., FLAVELL, R.B., ROGERS, H.J. and LONSDALE, D.M. (1993). Partial characterization of the Nicotiana tabacum actin gene family - evidence for pollen-specific expression of one of the gene family members. Molecular \& General Genetics 240: 290-295.

THOMAS, S., OSMAN, K., DE GRAAF, B.H., SHEVCHENKO, G., WHEELER, M., FRANKLIN, C. and FRANKLIN-TONG, N. (2003). Investigating mechanisms involved in the self-incompatibility response in Papaver rhoeas. Philos Trans $R$ Soc Lond B Biol Sci 358: 1033-6.

THOMPSON, R.D. and KIRCH, H.H. (1992). The S locus of flowering plants: when selfrejection is self-interest. Trends Genet 8: 381-7.

THORSNESS, M.K., KANDASAMY, M.K., NASRALLAH, M.E. and NASRALLAH, J.B. (1993). Genetic ablation of floral cells in Arabidopsis. Plant Cell 5: 253-261.

TIAN, H.Q., ZHU, H. and RUSSELL, S.D. (2000). Calcium changes in ovules and embryo sacs of Plumbago zeylanica L. Sex Plant Reprod 13: 11-20.

TIWARI, S.C. and POLITO, V.S. (1990). The initiation and organization of microtubules in germinating pear (Pyrus communis L.) pollen. Eur J Cel/ Bio/ 53: 384-9.

TYERMAN, S.D., NIEMIETZ, C.M. and BRAMLEY, H. (2002). Plant aquaporins: multifunctional water and solute channels with expanding roles. Plant Cel/ Environ. 25: 173-194.

USHIJIMA, K., SASSA, H., DANDEKAR, A.M., GRADZIEL, T.M., TAO, R. and HIRANO, H. (2003). Structural and transcriptional analysis of the self-incompatibility locus of almond: identification of a pollen-expressed F-box gene with haplotypespecific polymorphism. Plant Cell 15: 771-81.

UWATE, W.J. and LIN, J. (1980). Cytological zonation of Prunus avium L. pollen tubes in vivo. JUltrastruct Res 71: 173-84.

VIDALI, L. and HEPLER, P.K. (1997). Characterization and localization of profilin in pollen grains and tubes of Lilium longiflorum. Cell Motil Cytoskeleton 36: 323-38.

VIDALI, L., MCKENNA, S.T. and HEPLER, P.K. (2001). Actin polymerization is essential for pollen tube growth. Mol Biol Cell 12: 2534-45.

VIDALI, L., YOKOTA, E., CHEUNG, A.Y., SHIMMEN, T. and HEPTER, P.K. (1999). P135-ABP from Lilium longiflorum pollen is the plant homologue of villin. Mol. Biol. Cell 10: 902.

VIELLE-CALZADA, J.P., THOMAS, J., SPILLANE, C., COLUCCIO, A., HOEPPNER, M.A. and GROSSNIKLAUS, U. (1999). Maintenance of genomic imprinting at the Arabidopsis medea locus requires zygotic DDM1 activity. Genes Dev 13:2971-82.

WENGIER, D., VALSECCHI, I., CABANAS, M.L., TANG, W.H., MCCORMICK, S. and MUSCHIETTI, J. (2003). The receptor kinases LePRK1 and LePRK2 associate in pollen and when expressed in yeast, but dissociate in the presence of style extract. Proc. Natl. Acad. Sci. USA 100: 6860-6865.

WETERINGS, K., WIM, R.J., VANAARSSEN, R., KORTSTEE, A., SPIJKERS, J., VANHERPEN, M., SCHRAUWEN, J. and WULLEMS, G. (1992). Characterization of a pollen-specific cDNA clone from Nicotiana tabacum expressed during microgametogenesis and germination. Plant Mol. Biol. 18: 1101-1111.

WHEELER, M.J., FRANKLIN-TONG, V.E. and FRANKLIN, F.C.H. (2001). The molecular and genetic basis of pollen-pistil interactions. New Phytol 151: 565-584.

WISNIEWSKA, J., TREJGELL, A. and TRETYN, A. (2003). Plant signalling peptides. Acta Physiol. Plant. 25: 105-122.

WITTINK, F.R.A., KNUIMAN, B., DERKSEN, J., CAPKOVA, V., TWELL, D., SCHRAUWEN, J.A.M. and WULLEMS, G.J. (2000). The pollen-specific gene Ntp303 encodes a 69-kDa glycoprotein associated with the vegetative membranes and the cell wall. Sex Plant Reprod 12: 276-284.

WOLTERS-ARTS, M., LUSH, W.M. and MARIANI, C. (1998). Lipids are required for directional pollen-tube growth. Nature 392: 818-21.

WOLTERS-ARTS, M., VAN DER WEERD, L., VAN AELST, A.C., VAN DER WEERD, J., VAN AS, H. and MARIANI, C. (2002). Water-conducting properties of lipids during pollen hydration. Plant Cell Environ 25: 513-519.

WU, G., GU, Y., LI, S. and YANG, Z. (2001). A genome-wide analysis of Arabidopsis Rop-interactive CRIB motif-containing proteins that act as Rop GTPase targets. The Plant Cell 13: 2841-56.

WU, H.M., WANG, H. and CHEUNG, A.Y. (1995). A pollen tube growth stimulatory glycoprotein is deglycosylated by pollen tubes and displays a glycosylation gradient in the flower. Cell 82: 395-403.

WU, H.M., WONG, E., OGDAHL, J. and CHEUNG, A.Y. (2000). A pollen tube growthpromoting arabinogalactan protein from Nicotiana alata is similar to the tobacco TTS protein. Plant $J$ 22: 165-76.

WU, Y., QIU, X., DU, S. and ERICKSON, L. (1996). PO149, a new member of pollen pectate lyase-like gene family from alfalfa. Plant Mol Biol 32: 1037-42.

YADEGARI, R., KINOSHITA, T., LOTAN, O., COHEN, G., KATZ, A., CHOI, Y., NAKASHIMA, K., HARADA, J.J., GOLDBERG, R.B., FISCHER, R.L. et al. (2000) Mutations in the FIE and MEA genes that encode interacting polycomb proteins cause parent-of-origin effects on seed development by distinct mechanisms. Plant Cell 12: 2367-2382.

ZHANG, X.S. and O'NEILL, S.D. (1993). Ovary and gametophyte development are coordinately regulated by auxin and ethylene following pollination. Plant Ce//5: 403 418.

ZHENG, Z.L. and YANG, Z.B. (2000). The Rop GTPase switch turns on polar growth in pollen. Trends Plant Sci 5: 298-303.

ZINKL, G.M. and PREUSS, D. (2000). Dissecting Arabidopsis pollen-stigma interactions reveals novel mechanisms that confer mating specificity. Ann Bot-London 85: 15-21.

ZINKL, G.M., ZWIEBEL, B.I., GRIER, D.G. and PREUSS, D. (1999). Pollen-stigma adhesion in Arabidopsis: a species-specific interaction mediated by lipophilic molecules in the pollen exine. Development 126: 5431-40.

ZONIA, L., CORDEIRO, S. and FEIJO, J.A. (2001). Ion dynamics and hydrodynamics in the regulation of pollen tube growth. Sex. Plant Reprod. 14: 111-116.

ZONIA, L., CORDEIRO, S., TUPY, J. and FEIJO, J.A. (2002). Oscillatory chloride efflux at the pollen tube apex has a role in growth and cell volume regulation and is targeted by inositol 3,4,5,6-tetrakisphosphate. Plant Ce/l 14: 2233-49. 